\title{
Langer doorwerken, werksituatie en productiviteit : vervolgmeting (2009) VPL-onderzoek
}

Citation for published version (APA):

de Grip, A., \& Montizaan, R. M. (2010). Langer doorwerken, werksituatie en productiviteit : vervolgmeting (2009) VPL-onderzoek. Researchcentrum voor Onderwijs en Arbeidsmarkt, Faculteit der Economische Wetenschappen. ROA Reports No. 8 https://doi.org/10.26481/umarep.2010008

Document status and date:

Published: 01/01/2010

DOI:

10.26481/umarep.2010008

Document Version:

Publisher's PDF, also known as Version of record

\section{Please check the document version of this publication:}

- A submitted manuscript is the version of the article upon submission and before peer-review. There can be important differences between the submitted version and the official published version of record.

People interested in the research are advised to contact the author for the final version of the publication, or visit the DOI to the publisher's website.

- The final author version and the galley proof are versions of the publication after peer review.

- The final published version features the final layout of the paper including the volume, issue and page numbers.

Link to publication

\footnotetext{
General rights rights.

- You may freely distribute the URL identifying the publication in the public portal. please follow below link for the End User Agreement:

www.umlib.nl/taverne-license

Take down policy

If you believe that this document breaches copyright please contact us at:

repository@maastrichtuniversity.nl

providing details and we will investigate your claim.
}

Copyright and moral rights for the publications made accessible in the public portal are retained by the authors and/or other copyright owners and it is a condition of accessing publications that users recognise and abide by the legal requirements associated with these

- Users may download and print one copy of any publication from the public portal for the purpose of private study or research.

- You may not further distribute the material or use it for any profit-making activity or commercial gain

If the publication is distributed under the terms of Article $25 \mathrm{fa}$ of the Dutch Copyright Act, indicated by the "Taverne" license above, 


\title{
Langer doorwerken, werksituatie en productiviteit Vervolgmeting (2009) VPL-onderzoek
}

\author{
Andries de Grip
}

Raymond Montizaan

ROA-R-2010/8 


\section{Colofon}

(C) Researchcentrum voor Onderwijs en Arbeidsmarkt (ROA). Niets uit deze uitgave mag op enige manier worden verveelvoudigd zonder voorafgaande schriftelijke toestemming van de directeur van het ROA.

\section{Researchcentrum voor Onderwijs en Arbeidsmarkt}

School of Business and Economics

Maastricht University

\section{Vormgeving}

ROA secretariaat, Maastricht

\section{Verkoop}

Researchcentrum voor Onderwijs en Arbeidsmarkt email: secretary-roa-sbe@maastrichtuniversity.nl website: www.roa.nl

ISBN: 978-90-532I-490-9

juli 2010 


\section{Inhoud}

Resumé

V

1 Inleiding 1

$\begin{array}{lll}2 & \text { Schok in pensioenstelsel } & 7\end{array}$

3 Financiële prikkels en duurzame inzetbaarheid $\quad 17$

4 Active aging in de sector Overheid en Onderwijs 21

5 Financiële prikkels en pensioengedrag van de partner 29

6 Conclusie 31 


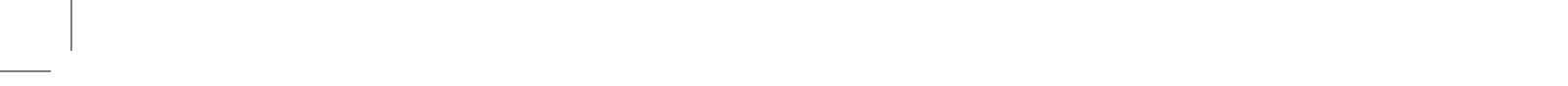




\section{Resumé}

In dit rapport dat is uitgevoerd door ROA in samenwerking met ABP wordt ingegaan op de vraag in hoeverre de organisaties binnen de overheid en het onderwijs succesvol zijn in het stimuleren van het (productief) langer doorwerken van hun werknemers. ${ }^{1}$ Daarbij wordt specifiek gekeken naar de effecten van de invoering van het ABP Keuzepensioen en het afschaffen van de FPU regeling in 2006 die beoogde de arbeidsmarktparticipatie van oudere werknemers te verhogen. Werknemers die geboren zijn in 1950 hebben geen recht meer op de oude meer genereuze prepensioenrechten (FPU) en zullen daardoor langer moeten doorwerken, terwijl degenen die geboren zijn in 1949 nog gebruik kunnen maken van de oude FPU-regeling.

\section{Effectiviteit financiële prikkels om langer door te werken is beperkt}

Uit de onderzoeksuitkomsten kan worden geconcludeerd dat veel werknemers die geboren zijn in 1950 toch vervroegd met pensioen willen gaan en vooral de levensloopregeling aanspreken om dit te verwezenlijken. Daarnaast zijn zij ook vaker voor hun pensioen gaan sparen, beleggen of hebben ze lijfrentepolissen afgesloten. Dit betekent dat de vervanging van de FPU door het ABP Keuzepensioen slechts in beperkte mate zal leiden tot een verhoogde arbeidsmarktparticipatie en dat de financiële prikkels om langer door te werken dus slechts in beperkte mate effectief zijn.

\section{Effecten financiële prikkels verschillen sterk per sector}

Er moet echter ook worden geconcludeerd dat er op dit punt grote verschillen zijn tussen de verschillende sectoren in de Overheid en het Onderwijs. Met name de werknemers in de sectoren Gemeenten, Rijk, Primair en het Voortgezet onderwijs denken als gevolg van de versobering van hun pensioenrechten langer door te werken. De prikkelende werking van het ABP Keuzepensioen is in deze sectoren veel groter omdat veel werknemers in deze sectoren voorheen eerder met pensioen dachten te gaan dan in andere sectoren. Ook wordt er in bepaalde sectoren vaker voor gekozen om de daling in het pensioen te compenseren door te participeren in de levensloop, of door volledig te blijven doorwerken in plaats met deeltijdpensioen te gaan (Universitair Medische Centra (UMC's) en Water, Energie en Nutsbedrijven).

I. Dit rapport is geschreven door Prof. dr. Andries de Grip en Drs. Raymond Montizaan. Beide auteurs zijn werkzaam bij het Researchcentrum voor Onderwijs en de Arbeidsmarkt (ROA). De bevindingen en meningen die worden gegeven in dit rapport komen uitsluitend voor rekening van de auteurs en reflecteren niet noodzakelijkerwijs die van het $\mathrm{ABP}$ of het ROA. 


\section{Versobering pensioenrechten ook effect op pensioengedrag partner}

Het effect van de vervanging van de FPU door het ABP Keuzepensioen blijft overigens niet beperkt tot de persoon met versoberde pensioenrechten. Partners van de mannen die in 1950 geboren zijn stellen hun pensioen met ongeveer drie maanden uit. Dit duidt erop dat echtparen samen met pensioen willen en besluiten om gezamenlijk hun pensioen uit te stellen als één van hen langer door moet werken

\section{Werknemers die langer door moeten werken zijn minder productief}

Werknemers die door de verslechtering van hun pensioenrechten gedwongen worden om later met pensioen te gaan, of een lagere pensioenuitkering te accepteren, zijn blijvend minder tevreden met hun leven, minder tevreden met hun baan en vaker depressief. Daardoor is het zeer waarschijnlijk dat de vervanging van de FPU door het ABP Keuzepensioen een negatief effect heeft op de productiviteit van oudere werknemers. Dit leidt tot de belangrijke conclusie dat wanneer uitsluitend financiële prikkels worden ingezet om de vervroegde pensionering af te remmen, de duurzame inzetbaarheid van oudere werknemers in feite verslechtert.

\section{Effectief beleid gericht op de duurzame inzetbaarheid omvat meer dan alleen financiële prikkels}

Het geven van financiële prikkels om langer door te werken staat daardoor op gespannen voet met de productiviteitsagenda. Het is zelfs mogelijk dat de beperkte positieve prikkel op de arbeidsmarktparticipatie (mensen geboren in 1950 denken drie maanden later met pensioen te gaan dan degenen die geboren zijn in 1949), volledig teniet gedaan wordt door de verlaagde productiviteit. Immers, gemiddeld genomen zullen werknemers die geboren zijn in I950 op het moment van de enquête nog ruim vijf jaar moeten werken voordat zij hun verwachte pensioenleeftijd zullen bereiken. Als ze al deze jaren minder plezier hebben in hun werk lijkt het beleid op dit punt zijn doel voorbij te schieten. Een belangrijke conclusie die hieruit kan worden getrokken is dat een effectief beleid gericht op de duurzame inzetbaarheid van oudere werknemers niet uitsluitend gericht moet zijn op het vergroten van de financiële prikkels om langer door te werken. Een goed active aging beleid is noodzakelijk om de demotiverende werking van financiële maatregelen te compenseren en om de productiviteit van oudere werknemers op peil te houden. 


\section{Oudere werknemers oordelen negatief over het gevoerde personeelsbeleid}

In alle sectoren binnen de overheid oordelen oudere werknemers vrij negatief over het door hun werkgever gevoerde personeelsbeleid. Relevant is dat het hier dus uitsluitend gaat om de percepties van werknemer. Desalniettemin is het opvallend dat werknemers die langer door moeten werken in het Primair en Wetenschappelijk onderwijs slechter oordelen ten opzichte van degenen die nog met FPU kunnen. Dit duidt erop dat het huidige personeelsbeleid in deze sectoren nog niet in voldoende mate is ingespeeld op het nieuwe pensioensysteem. Werkgevers zetten zich volgens de werknemers ook te weinig in om oudere werknemers langer aan het werk te houden.

Verder blijkt dat het gevoerde personeelsbeleid in de sectoren Rijk en de Provincies en de Waterschappen het best wordt beoordeeld. In deze sectoren zijn de werknemers duidelijk positiever over de bereidheid van hun werkgever om de taakbelasting aan te passen, de mogelijkheden om in deeltijd te werken en over de feedback die zij krijgen van hun leidinggevende. Daarbij komt nog dat bij het Rijk de werknemers met versoberde pensioenrechten iets positiever oordelen over de feedback die zij krijgen over hun ontwikkeling dan degenen die nog met FPU kunnen.

De andere sectoren blijven op dit punt echter achter. De sector Beroeps- en Volwasseneneducatie scoort, op alle beleidsonderdelen lager. Maar 31\% van de werknemers in deze sector geeft aan dat hun werkgever bereid is om hun taakbelasting aan te passen indien dat noodzakelijk is en krijgt ook feedback over hun doorgroeimogelijkheden. Bovendien ligt het percentage werknemers dat in deeltijd zou kunnen werken gemiddeld genomen $7 \%$-punt lager dan in andere sectoren.

Verder valt op dat werknemers die minder pensioenrechten hebben vanwege de afschaffing van de FPU net zo negatief oordelen over het personeels- en ouderenbeleid van hun werkgever als degenen die zijn geboren in 1949 en nog steeds met FPU kunnen. Dit suggereert dat werkgevers nog geen of in ieder geval onvoldoende extra beleid hebben ontwikkeld voor de werknemers die langer door zullen moeten werken.

Wat betreft het trainingsbeleid scoort de overheidssector en het onderwijs een stuk beter. Het percentage oudere werknemers dat nog participeert in een training is hoog in verhouding met de private sector. Bovendien hebben de werknemers met versoberde pensioenrechten die werkzaam zijn in grote organisaties meer training ontvangen dan diegenen die nog met FPU kunnen. 


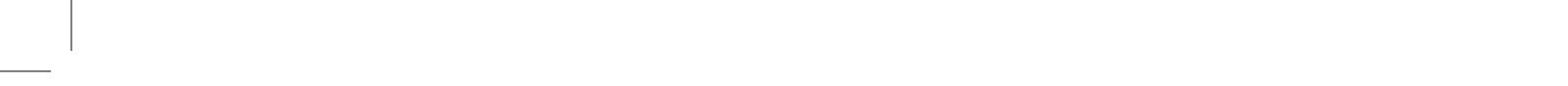




\section{Inleiding}

In de komende decennia zal de vergrijzing van de werkzame bevolking in Nederland grote effecten hebben op de arbeidsmarkt. Veel oudere werknemers zullen de komende jaren de arbeidsmarkt verlaten. Hierdoor zal de vervangingsvraag toenemen terwijl de arbeidsmarktinstroom van schoolverlaters achterblijft. Als gevolg hiervan kan verwacht worden dat na de huidige economische crisis op de middellange termijn op verschillende segmenten van de arbeidsmarkt aanzienlijke knelpunten in de personeelsvoorziening zullen ontstaan. Op de wat langere termijn zal deze vervangingsvraag nog verder toenemen. Het Centraal Planbureau (CPB) heeft de langetermijneffecten van de demografische trends in Nederland op het arbeidsaanbod door middel van vier langetermijnscenario's gekwantificeerd. ${ }^{2}$ Uit deze scenarioanalyses blijkt dat de demografische ontwikkelingen in drie van de vier scenario's tot het jaar 2040 een negatief effect zullen hebben op het arbeidsaanbod. Met andere woorden: de uitstroom uit de arbeidsmarkt zal groter zijn dan de arbeidsmarktinstroom. Hoewel dit gunstig is voor de arbeidsmarktperspectieven van schoolverlaters die op de arbeidsmarkt instromen, zorgt de vergrijzing ervoor dat werkgevers meer moeite zullen krijgen om hun personeelsbestand in kwantitatieve of kwalitatieve zin op peil te houden.

De Overheid en sociale partners zijn zich in toenemende mate bewust van de vergrijzingproblematiek. Vanaf de jaren ' 90 heeft dit geleid tot een groeiend aantal maatregelen en initiatieven om de arbeidsmarktparticipatie te vergroten, onder meer door werknemers te stimuleren om langer door te werken. Daarbij kunnen er in principe twee beleidsagenda's worden onderscheiden:

- een participatie-agenda

- een productiviteitsagenda

De participatie-agenda heeft betrekking op het beleid gericht op een hogere arbeidsparticipatie (van alle leeftijdscohorten) en bevat vooral maatregelen die mensen financieel prikkelen om langer op de arbeidsmarkt actief te blijven. Voorbeelden van dergelijke maatregelen zijn de afschaffing van de VUT en het prepensioen, het actuarieel neutraal maken van pensioenschema's en striktere toelatingseisen voor arbeidsongeschiktheidsuitkeringen. De productiviteits-agenda is daarentegen meer gericht op het van de grond krijgen van een levensfasebewust ('active aging') personeelsbeleid met het doel om de duurzame inzetbaarheid van het oudere personeel te vergroten. Het active aging beleid gaat uit van maatwerk om zo een werkomgeving te creëren die elk indi-

2. Roodenburg, H., en D. van Vuur (2004), Arbeidsaanbod in de lange-termijnscenario's voor Nederland, CPB Document 7I, Den Haag. 
vidu stimuleert om te blijven doorwerken. Terwijl de financiële prikkels vervroegde uittreding duurder maken, is active aging beleid bedoeld om mensen intrinsiek te motiveren om langer door te werken en hun productiviteit op peil te houden. Met andere woorden, terwijl de participatie-agenda zich beperkt tot het stimuleren van de arbeidsparticipatie van ouderen, gaat de productiviteitsagenda een stap verder door zich te richten op een duurzame en productieve arbeidsdeelname van ouderen. In vergelijking met de participatie-agenda is de productiviteitsagenda echter pas vrij laat onder de aandacht gekomen. De Raad voor het Overheidspersoneelsbeleid (ROP) benadrukte in het advies "Vluchten kan niet meer" (2005) de relevantie van een active aging beleid voor de sector Overheid en Onderwijs. Voor de overheid en het onderwijs heeft de Raad voor het Overheidspersoneelsbeleid (ROP) vanuit het V-model vijf onderdelen gedefinieerd die active aging beleid succesvol kunnen maken:

- Verkennen van mogelijkheden om langer door te werken

- Voorlichten van zowel werkgever als werknemer

- Vitaliseren van werknemers (bijvoorbeeld via training)

- Verlichting (taakbelasting aanpassen) en

- Vertrekken (ander werk of stoppen met werken als langer doorwerken niet mogelijk is).

Daaropvolgend heeft de regering in 2007 in het beleidsprogramma 2007-20II "Samen leven, samen werken" expliciet een passage opgenomen waarin zij aangeeft dat het kabinet contact wil hebben met de sociale partners om leeftijdsbewust personeelsbeleid te stimuleren. Intussen zijn al verschillende aandachtspunten uit het beleidsplan 2007-20II concreet uitgewerkt, zoals in het project "Iedereen doet mee" en in het "Actieteam Talent45+". Deze projecten richten zich echter uitsluitend op de participatie-agenda. Tot een nadere concretisering van de productiviteitsagenda is het echter nog niet gekomen.

De vergrijzing is niet in alle sectoren even sterk. Zo is het percentage werknemers van 50 jaar en ouder in de Horeca ( $15 \%$ ), Zakelijke Dienstverlening en het Bankwezen (beide $17 \%$ ) erg laag (Bron: ROA/AIS 2007-2008). Daarentegen is dit percentage in de Overheidssectoren en het Onderwijs erg hoog (zie Figuur I.I). In het Onderwijs is zelfs ruim $37 \%$ van de werknemers 50 jaar of ouder. Verwacht mag daarom worden dat in de Overheidssectoren en het Onderwijs de komende jaren veel werknemers de arbeidsmarkt zullen verlaten. Daardoor zullen de knelpunten in de personeelsvoorziening op de arbeidsmarktsegmenten die van belang zijn voor de Overheid en het Onderwijs naar verwachting relatief groot zijn. De Overheid en het Onderwijs hebben er daarom veel baat bij om de arbeidsmarktparticipatie van oudere medewerkers te stimuleren op basis van een active aging beleid gericht op een duurzame inzetbaarheid van het oudere personeel.

In dit rapport dat is uitgevoerd door ROA in samenwerking met $\mathrm{ABP}$ wordt ingegaan op de vraag in hoeverre de organisaties binnen de Overheid en het Onderwijs succesvol zijn in het stimuleren van het (productief) langer doorwerken van hun werknemers. Daarbij wordt specifiek gekeken naar de effecten van de invoering van 
het ABP Keuzepensioen en het afschaffen van de FPU regeling in 2006 die beoogde de arbeidsmarktparticipatie van oudere werknemers te verhogen. Daarnaast wordt onderzocht in hoeverre er een goed active aging beleid wordt gevoerd in de Overheid en het Onderwijs. In tegenstelling tot voorafgaande rapporten wordt daarbij in meer detail ingegaan op de sectorale verschillen in de reacties van werkgevers op de hervorming van het pensioensysteem. Tevens wordt het effect van de versobering van pensioenrechten op het pensioengedrag van de partner nader geanalyseerd. Het uittredebesluit is immers doorgaans geen individuele beslissing, maar wordt gezamenlijk gemaakt met de partner.

\section{Figuur 1.1}

Leeftijdsopbouw van de werkenden in de sectoren Onderwijs, Overheid en totaal (\%) gemiddelde 2007-2008

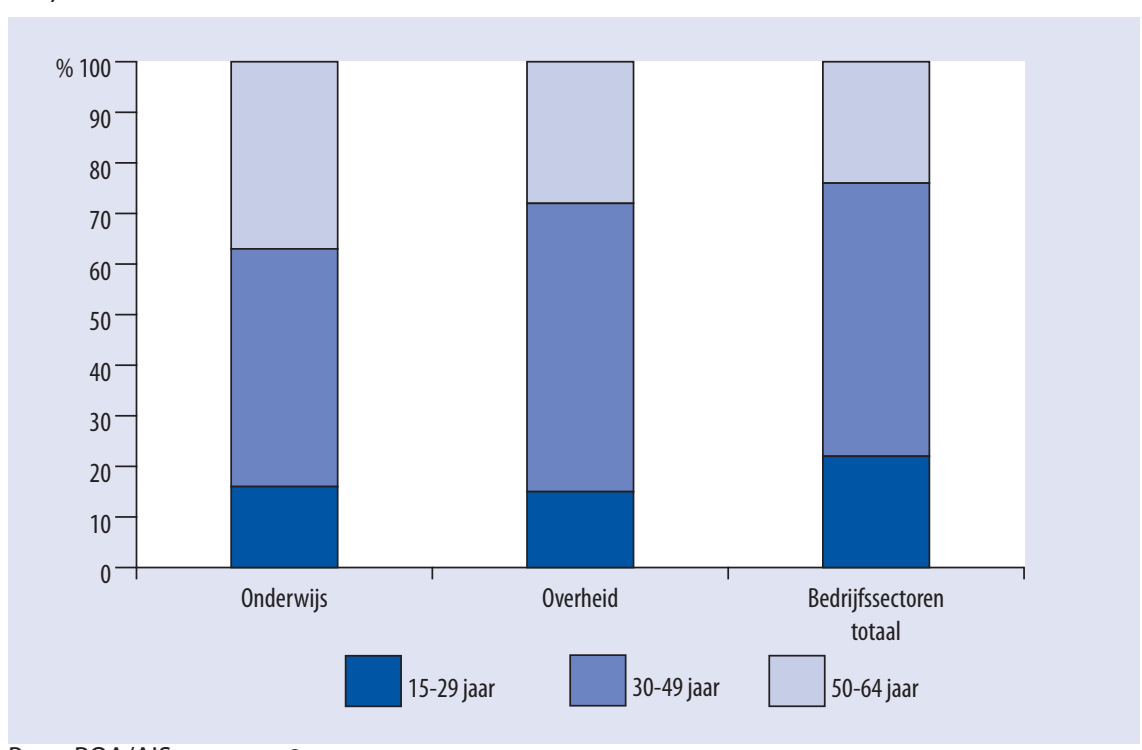

Bron: ROA/AIS, 2007-2008

Geprobeerd zal worden om de volgende vier onderzoeksvragen te beantwoorden:

- In hoeverre stimuleren financiële prikkels het langer doorwerken? Wat zijn de mogelijke negatieve effecten van financiële prikkels op de duurzame inzetbaarheid van oudere werknemers en hebben werknemers hun verwachtingen aangepast na de schok in hun pensioenrechten?

- Hebben financiële prikkels tot langer doorwerken effect op het pensioengedrag van de partner?

- In hoeverre hebben werkgevers in de sector Overheid en het Onderwijs een active aging beleid ontwikkeld om de mensen met versoberde pensioenrechten intrinsiek te motiveren om langer door te werken?

- In welke mate verschillen de initiatieven om active aging beleid te ontwikkelen tussen de verschillende sectoren binnen de Overheid en het Onderwijs? 
Om deze vragen te beantwoorden zullen wij gebruik maken van een unieke dataset waarin uitgebreide informatie beschikbaar is over het active aging beleid, werkmotivatie, pensioenrechten en het verwachte inkomen na pensionering binnen de Overheidssector en het Onderwijs. De dataset bestaat uit een combinatie van surveydata met administratieve data van het $\mathrm{ABP}$ en heeft betrekking op drie enquêtes die zijn gehouden in de jaren 2007-2009 onder een representatief panel van mannelijke full-time werknemers die zijn geboren in 1949 of 1950 . De steekproef is verder beperkt tot mannen die reeds sinds 1997 in de publieke sector werkzaam waren en niet vallen onder afwijkende regelingen. ${ }^{3}$

In 2007 bedroeg de bruikbare surveyrespons 7.019, waarvan 3.692 mannen die geboren zijn in 1950 en 3.327 mannen die geboren zijn in 1949. ${ }^{4}$ In 2008 en 2009 bestond de bruikbare respons uit respectievelijk 5.559 en 6.62I mannen. Het unieke van deze dataset is dat de gegevens betrekking hebben op een homogene groep werknemers met verschillende pensioenrechten vanwege de invoering van het ABP Keuzepensioen. Werknemers die geboren zijn in 1950 hebben geen recht meer op de oude meer genereuze prepensioenrechten (FPU) en zullen daardoor langer moeten doorwerken, terwijl degenen die geboren zijn in 1949 nog gebruik kunnen maken van de oude FPU-regeling. Vanwege het experimentele karakter van de data is het mogelijk om de causale relatie tussen de (exogene) veranderingen in de pensioenrechten en de meest relevante facetten van het active aging beleid en het verwachte uittredegedrag te analyseren..$^{5}$ Daarbij gaat het in feite om de vraag in hoeverre werkgevers hun personeelsbeleid hebben aangepast voor werknemers die door minder genereuze pensioenrechten worden gedwongen om langer door te werken. Oftewel, vult de productiviteitsagenda de participatie-agenda voldoende aan? Zonder het experimentele karakter en de panelstructuur zou het moeilijk zijn om causale verbanden te kunnen vaststellen omdat het dan onduidelijk is of de anticipatie van werknemers op een bepaalde pensioenleeftijd hun houding ten opzichte van active aging beleid beïnvloedt, of dat active aging beleid juist leidt tot uitstel van pensionering. Trainingsparticipatie kan bijvoorbeeld gestimuleerd worden doordat werknemers later met pensioen gaan, maar het volgen van training kan ook de oorzaak zijn van uitstel van pensionering. In dit onderzoek ligt het causale verband echter vast: degenen die geboren zijn in 1950 zullen langer moeten doorwerken om dezelfde pensioenrechten

3. Het merendeel van de mannelijke employees die geboren zijn in 1949 of 1950 zijn kostwinner terwijl vrouwen die geboren zijn in deze twee jaren vaak een onderbroken loopbaan hebben. In deze leeftijdsgroep hebben mannen gemiddeld genomen 28 jaar pensioen opgebouwd terwijl vrouwen maar I6 jaar hebben opgebouwd. Bovendien, is alleen een kleine selectieve groep van deze vrouwen nog steeds werkzaam (30\% van alle werknemers geboren in 1949 en 1950), waarvan $72 \%$ ook nog eens werkt in een parttime baan (CBS, Statline 2005). Daarbij geldt eveneens dat deze groep vrouwen niet representatief is voor jongere cohorten.

4. Om het onderscheid in de pensioenrechten zo scherp mogelijk te houden tussen werknemers die geboren zijn in 1949 of 1950 , vallen de mensen die onder een FLO regeling vallen zoals degenen die werkzaam zijn bij de politie, brandweer of ambulancedienst evenals militair personeel in dit onderzoek buiten beschouwing.

5. Het onderscheid in de pensioenrechten tussen werknemers die in 1949 en 1950 zijn geboren kan worden aangeduid als een 'natuurlijk experiment'. 
op te bouwen als van de mensen die geboren zijn in 1949. Voor de eerstgenoemde groep geldt dat vervroegd pensioneren voor de leeftijd van 65 jaar relatief meer geld kost naarmate iemand eerder wil stoppen met werken.

Een bijkomend voordeel is dat de data voor dezelfde personen beschikbaar zijn in drie opeenvolgende jaren. Het monitoren van zowel sectoren als de individuele medewerkers over een aantal jaren kan de mogelijke ontwikkeling van het active aging beleid en de pensioenplannen van de respondenten goed in kaart brengen. Hierdoor kunnen we zien in hoeverre werknemers die geen recht meer hebben op de FPU regeling in de loop van de tijd hun pensioenverwachtingen hebben bijgesteld of actie hebben ondernomen om hun pensioen aan te vullen naarmate zij dichter bij hun pensioen komen.

Dit rapport is als volgt opgebouwd. In Hoofdstuk 2 wordt ingegaan op de schok in het pensioenstelsel en het 'natuurlijk experiment' dat wordt benut om de bovenstaande vragen te beantwoorden. Het hoofdstuk bevat analyses van de gevolgen van de financiële prikkels op het verwachte uittredegedrag. Passen mensen hun pensioenverwachtingen aan in de periode 2006-2009! En, in hoeverre zijn werknemers in staat om de financiële prikkels (gedeeltelijk) te compenseren door hun pensioenbesparingen te verhogen en maken zij gebruik van deeltijdpensionering en de levensloopregeling? Hoofdstuk 3 analyseert of de financiële prikkels negatieve effecten hebben op de duurzame inzetbaarheid van de werkenden. Er wordt aandacht besteed aan het effect van financiële prikkels om langer door te werken op de algemene tevredenheid, de werkmotivatie en de gezondheid van de werknemers. Hoofdstuk 4 bevat een analyse van het gevoerde active aging beleid in de Overheids- en Onderwijssector. Daarbij wordt gekeken of de productiviteitsagenda de participatie-agenda voldoende aanvult en of er in de verschillende sectoren sprake is van maatwerk gericht op de werknemers die door de hervorming van het pensioensysteem langer zullen doorwerken. Hoofdstuk 5 onderzoekt de externe effecten van de schok in het pensioensysteem op pensioengedrag van partners. In Hoofdstuk 6 vatten we het onderzoek samen en geven wij enkele beleidsaanbevelingen. 


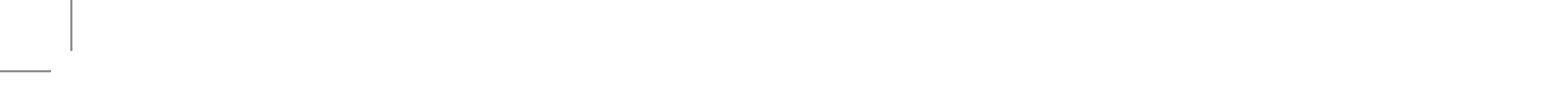




\section{Schok in pensioenstelsel}

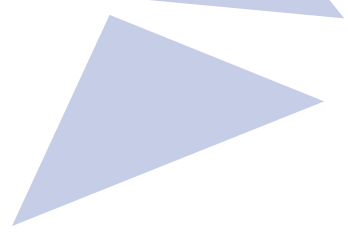

In dit hoofdstuk gaan wij in op de effecten van de vermindering van de pensioenrechten in 2006 op de pensioenverwachtingen. Het vervallen van de FPU rechten in combinatie met de invoering van het ABP Keuzepensioen kan vanuit onderzoeksperspectief worden gezien als een natuurlijk experiment, waarbij werknemers van vrijwel dezelfde leeftijd worden geconfronteerd met verschillende pensioenrechten. Hierdoor is het eenvoudig om het effect van financiële prikkels op het gedrag van werknemers te analyseren. De werknemers die geboren zijn in 1950 vallen namelijk sinds I januari 2006 onder ABP Keuzepensioen en zullen noodgedwongen langer moeten doorwerken indien zij bij vervroegde pensionering dezelfde pensioenuitkering wensen te ontvangen, terwijl de werknemers die geboren zijn in 1949 (en op I januari 2006 minstens Io jaar werkzaam waren bij de Overheid of in het Onderwijs) nog gebruik kunnen maken van de oude FPU regeling. Verschillende kenmerken van het nieuwe pensioensysteem geven aan de werknemers die zijn geboren in 1950 prikkels om langer door te werken:

- $\mathrm{Zij}$ worden geconfronteerd met een daling in hun pensioenuitkering tenzij ze later met pensioen gaan;

- De hoogte van hun pensioenuitkering hangt in sterkere mate af van de leeftijd waarop zij met pensioen zullen gaan, dan bij degenen die in 1949 zijn geboren.

- Werknemers wordt de mogelijkheid geboden om tussen 60 en 70 jaar uit te treden

De implicaties hiervan zijn dat een werknemer met een 40-jarig dienstverband die geboren is in 1950 ongeveer één jaar en één maand langer moet werken om de oude norm van een vervangingsratio van $70 \%$ te bereiken (van het middelloon). Daarentegen, werknemers die geboren zijn in 1949 en sinds I april 1997 continu hebben gewerkt bij een organisatie in de Overheidsector of Onderwijs, kunnen bij een 40-jarig dienstverband op een leeftijd van 62 jaar en 3 maanden tegen een vervangingsratio van $70 \%$ van hun middelloon met pensioen.

\section{Effect van afschaffing FPU op de verwachte pensioendatum}

In hoeverre stimuleren financiële prikkels het langer doorwerken? Tabel 2.I laat zien dat degenen die geboren zijn in 1950 langer denken door te werken dan degenen die geboren zijn in 1949. In 2007 dacht de gemiddelde werknemer die nog recht heeft op FPU uit te treden als hij 62 jaar en zes maanden oud is. Daarentegen verwachten 
de werknemers die geboren zijn in 1950 gemiddeld genomen met pensioen te gaan als zij 63 jaar en 5 maanden oud zijn. Interessant is dat beide groepen op de leeftijd waarop zij met pensioen denken te gaan, indien zij 40 dienstjaren hebben, ongeveer een pensioeninkomen hebben ter hoogte van ongeveer $70 \%$ van het brutoloon.

De tabel laat echter ook zien dat de financiële prikkels op de langere termijn minder groot zijn dan direct na de herziening van het pensioenstelsel. Opvallend is dat zowel de werknemers die geboren zijn in 1949 als diegenen die geboren zijn in 1950 in 2008 de verwachte pensioenleeftijd naar beneden hebben bijgesteld. Na de bijstelling van de pensioenverwachtingen is het verschil in de pensioenleeftijd tussen de mensen die geboren zijn in 1949 of 1950 nog maar drie maanden. In 2009 is voor beide groepen weer een stijging van de verwachten pensioenleeftijd te zien, waarschijnlijk als gevolg van het toegenomen pessimisme dat is ontstaan door de economische crisis en de verslechtering van de dekkingsgraad van het $\mathrm{ABP}$ die van invloed zijn op de indexatie van de pensioenen. Door de financiële crisis denken mensen ruim een jaar langer te moeten doorwerken. Echter, ook in 2009 blijft het verschil in de verwachte pensioenleeftijd tussen beide geboortejaren beperkt tot maar drie maanden. Dit wijst erop dat degenen die geen recht meer hebben op FPU genoegen lijken te nemen met een lager pensioen en daarbij toch eerder met pensioen willen gaan, of dat zij de daling in hun pensioen zelf op individuele basis proberen op te vullen.

Tabel 2.1

Impact versobering pensioenrechten op de verwachte pensioenleeftijd- en uitkering

$\begin{array}{rrr}1949 & 1950 \quad \begin{array}{r}\text { Significantie } \\ \text { verschil } \\ 1949-1950\end{array} \\ & \end{array}$

$\begin{aligned} & \text { Op welke leeftijd denkt u definitief te stoppen met werken } \\ & \text { (gemeten in jaren) }\end{aligned}$
2007
2008
2009

Stel u zou met 62 jaar met pensioen gaan. Hoe hoog denkt u dat uw pensioenuitkering dan zal zijn? In \% van uw netto salaris.

2007

Bent u op dit ogenblik met deeltijdpensioen of bent u van plan om met deeltijdpensioen te gaan?

De verschillen in de verwachte pensioenleeftijd en de pensioenuitkering van degenen die geboren zijn in 1949 of 1950 zijn in alle jaren significant op het 1\%-niveau. 
Tabel 2.I laat verder zien dat de verwachte pensioenuitkering als mensen 62 jaar zijn in de afgelopen jaren maar in beperkte mate is veranderd. Het meest opvallende is dat werknemers in 2009 minder optimistisch zijn over het pensioen dat zij zouden kunnen ontvangen op 62 jarige leeftijd. Het feit dat de daling voor beide groepen wordt waargenomen sterkt het vermoeden dat dit het gevolg is van de financiële crisis. Desalniettemin wordt ook in 2009 een significant verschil in de gemiddelde verwachte pensioenuitkering van 5\%-punt gemeten, dat nauwelijks afwijkt van het feitelijke verschil in pensioenrechten tussen de twee geboortejaren (6\%-punt). Interessant is dat mensen die geboren zijn in 1950 dus als gevolg van de afschaffing van de FPU goed op de hoogte zijn van hun lagere pensioenrechten en dat hun verwachtingen over hun pensioenuitkering na 2006 niet zijn veranderd, maar dat zij wel hun pensioenverwachtingen hebben bijgesteld. Terwijl ze ruim een jaar langer moeten doorwerken om het effect van hun versoberde pensioenrechten te compenseren, verwachten zij zowel in 2008 als 2009 maar drie maanden langer door te werken dan degenen die in 1949 zijn geboren en nog wel recht hebben op FPU. Hieruit blijkt duidelijk dat het geven van financiële prikkels voor veel mensen niet voldoende is om daadwerkelijk langer door te blijven werken

Ten slotte laat de tabel zien, dat mensen die geboren zijn in 1950 vaker aangeven dat zij van deeltijdpensioen gebruik willen gaan maken, dan diegenen die in 1949 geboren zijn. Het verschil is echter statistisch niet significant.

Tabel 2.2 toont aan dat de mate waarin de werknemers die geboren zijn in 1950 langer denken door te werken sterk verschilt per sector. De tabel laat zien dat werknemers in het Wetenschappelijk Onderwijs die geboren zijn in 1950 significant later denken uit te treden (op een leeftijd van 63 jaar en acht maanden) dan in andere sectoren, terwijl werknemers die werken in de sectoren Defensie Burger, Beroepsen Volwasseneneducatie en Water, Energie- en Nutsbedrijven juist significant eerder denken uit te treden.

De vraag is vervolgens wat de impact is van de versobering in pensioenrechten op de verwachte pensioenleeftijd in de sectoren. Met andere woorden, kan de hogere verwachte pensioenleeftijd van degenen die geboren zijn in 1950 in het Wetenschappelijk onderwijs verklaard worden door de schok in het pensioensysteem, of treden alle werknemers in deze sector later uit.

Een vergelijking van het 1949 cohort met diegenen die geboren zijn in 1950 laat zien dat vooral de werknemers in de sectoren Rijk, Gemeenten, Primair en Voortgezet Onderwijs en Water, Energie en Nutsbedrijven denken als gevolg van hun versoberde pensioenrechten langer door te gaan werken. Interessant is daarbij dat de grote impact van de pensioenhervorming op de werknemers in deze sectoren deels het gevolg is van het feit dat de werknemers die geboren zijn in 1949 in deze sectoren relatief vroeg met pensioen denken te gaan. Het is daarom het weinig verrassend dat de financiële 
prikkels juist in deze sectoren een grotere impact hebben, aangezien in deze sectoren waarschijnlijk voorheen alle mensen relatief vroeg met pensioen gingen.

Daarentegen verwachten de werknemers in het Hoger Beroepsonderwijs, Wetenschappelijk Onderwijs, en de UMC's in het algemeen juist later met pensioen te gaan. Daardoor is de impact van de invoering van het ABP-Keuzepensioen in deze sectoren ook kleiner en is het verschil in de verwachte pensioenleeftijd tussen degenen die in 1949 of in 1950 geboren zijn dus ook klein. Dit betekent dat de hoge uittredeleeftijd van diegenen die geboren zijn in 1950 in het Wetenschappelijk onderwijs waarschijnlijk niet wordt veroorzaakt door de versobering in de pensioenrechten van degenen die geboren zijn in $1950 .^{6}$

Tabel 2.2

Impact versobering pensioenrechten op de verwachte pensioenleeftijd in 2009 per sector

$\begin{array}{rrrrr}1949 \quad 1950 & \text { Significantie } & \text { Verschil in } & \text { Significantie } \\ \text { verschillen } & \text { pensioen } & \text { verschil } \\ & \text { tussen } & \text { leeftijd in } & 1949-1950 \\ & \text { sectoren } & \text { manden } & \\ & (1950) & \end{array}$

\begin{tabular}{|c|c|c|c|c|c|}
\hline \multicolumn{6}{|c|}{$\begin{array}{l}\text { Op welke leeftijd denkt u definitief te stoppen met werken } \\
\text { (gemeten in jaren) }\end{array}$} \\
\hline Rijk & 63,0 & 63,5 & & 6 & $* * *$ \\
\hline Defensie burger & 63,0 & 63,1 & * & 1 & \\
\hline Gemeenten & 62,8 & 63,5 & & 8 & $* * *$ \\
\hline Provincies en Waterschappen & 63,1 & 63,4 & & 4 & \\
\hline Primair Onderwijs & 62,9 & 63,4 & & 7 & $* * *$ \\
\hline Voortgezet Onderwijs & 63,1 & 63,5 & & 3 & $* * *$ \\
\hline Beroeps en volwasseneneducatie & 63,2 & 63,2 & $* *$ & 0 & \\
\hline Hoger beroepsonderwijs & 63,6 & 63,7 & & 1 & \\
\hline Wetenschappelijk onderwijs & 63,8 & 63,8 & * & 0 & \\
\hline Universitair medische centra & 63,6 & 63,5 & & -1 & \\
\hline Water, energie- en nutsbedrijven & 62,6 & 63,0 & $* * *$ & 5 & * \\
\hline Overig & 62,8 & 63,5 & & 8 & $* * *$ \\
\hline Totaal & 63,1 & 63,4 & & 0,3 & $* * *$ \\
\hline
\end{tabular}

6. Opmerkelijk is overigens ook dat in het Hoger Beroepsonderwijs en de UMC's de werknemers die geboren zijn in 1950 veel vaker hun pensioengat proberen te repareren door te investeren in de levensloopregeling (zie Tabel 2.8). 
De tabel laat tevens zien dat de relatief lage uittredeleeftijd van het 1950 cohort in de sectoren Defensie Burger, Beroeps- en Volwasseneneducatie en Water, Energie- en Nutsbedrijven grotendeels kan worden verklaard vanuit het zeer beperkte effect dat de vervanging van het FPU door het ABP-KeuzePensioen heeft gehad op de verwachte uittredeleeftijd in deze sectoren.

Hoewel de vervanging van FPU door het ABP Keuzepensioen dus niet voor elke sector een significant effect heeft op de verwachte pensioenleeftijd zijn er wel grote verschillen tussen de twee leeftijdscohorten in bijna alle sectoren in de pensioenuitkering die men verwacht als men met 62 jaar met pensioen zou gaan. De uitzondering is echter het Hoger Beroepsonderwijs.

Tabel 2.3

Impact versobering pensioenrechten op de verwachte pensioenuitkering in 2009 per sector

$\begin{array}{rrrrr}1949 & 1950 & \text { Significantie } & \text { Verschilin } & \text { Significantie } \\ \text { verschillen } & \text { pensioen } & \text { verschil } \\ \text { tussen } & \text { uitkering } & 1949-1950 \\ & \text { sectoren } & & \\ & (1950) & \end{array}$

\section{Stel u zou met 62 jaar met pensioen gaan. Hoe hoog} denkt u dat uw pensioenuitkering dan zal zijn? In \% van uw netto salaris

Rijk

Defensie burger

Gemeenten

Provincies en Waterschappen

Primair Onderwijs

Voortgezet Onderwijs

Beroeps en volwasseneneducatie

Hoger beroepsonderwijs

Wetenschappelijk onderwijs

Universitair medische centra

Water, energie- en nutsbedrijven

Overig

$\begin{array}{llll}69,3 & 63,4 & & -5,9 \\ 68,3 & 63,8 & & -4,5 \\ 72,5 & 65,6 & * * * & -6,9 \\ 68,9 & 65,0 & & -3,9 \\ 67,3 & 61,6 & * * & -5,7 \\ 66,7 & 62,4 & & -4,3 \\ 66,8 & 63,3 & & -3,5 \\ 60,7 & 60,0 & * * * & -0,7 \\ 64,8 & 61,3 & * & -3,5 \\ 63,0 & 58,3 & * * * & -4,7 \\ 75,6 & 67,2 & * * * & -8,4 \\ 70,3 & 62,8 & & -7,5\end{array}$

$68,4 \quad 63,4$

$-5,0$
$-5,9$

$-4,5$

$-6,9$

$-3,9$

$-5,7$

$-4,3$

$-3,5$

$-0,7$

$-3,5$

$-4,7$

$-8,4$

$-7,5$

Totaal

*** significant op 1\%-niveau, ** significant op 5\%-niveau, * significant op 10\%-niveau. De significantie van de verschillen tussen de sectoren is bepaald door middel van een OLS regressie vergelijking waarin dummy variabelen zijn opgenomen voor elke sector (Rijk is de referentiecategorie).

Tabel 2.3 laat echter ook zien dat de hoogte van de gemiddelde pensioenuitkering tussen de sectoren sterk verschilt. Degenen die werkzaam zijn in de sectoren 
Gemeenten of Water, Energie en Nutsbedrijven verwachten een significant hogere uitkering te ontvangen dan gemiddeld, terwijl werknemers in het Primair Onderwijs, Hoger Beroepsonderwijs en Wetenschappelijk Onderwijs en in de UMC's juist een significant lagere pensioenuitkering verwachten. Interessant daarbij is dat in de eerst genoemde sectoren de impact van de versobering van de pensioenrechten het grootst is (verschil van $6,9 \%$ en $8,4 \%$ ). Waarschijnlijk heeft de vervanging van de FPU door het ABP Keuzepensioen er toe heeft geleid dat in deze sectoren de werknemers die zijn geboren in 1950 hun verwachte pensioenuitkering sterker naar beneden hebben bijgesteld.

De verschillen in de populariteit van deeltijdpensionering tussen de verschillende sectoren zijn vrij klein. Desondanks laat Tabel 2.4 zien dat in de Provincies en Waterschappen, het Wetenschappelijk Onderwijs, UMC's en in de Water, Energie en Nutsbedrijven deeltijdpensionering iets minder vaak voorkomt. Deeltijdpensionering lijkt vaker toegepast te worden in het Primair Onderwijs en het Voortgezet onderwijs. Echter, het (geplande) gebruik van deeltijdpensionering in deze twee sectoren wijkt niet significant af van die in de overige sectoren.

Tabel 2.4 laat verder zien dat de versobering van de pensioenrechten ook weinig effect heeft op de mate waarin men van plan is om eerst een tijd met deeltijdpensioen te gaan voordat men zich helemaal terug trekt uit de arbeidsmarkt. Alleen in het Rijk is er tussen beide groepen een sterk significant verschil in het percentage werknemers dat verwacht gebruik te maken van deeltijdpensionering (of daar reeds gebruik van maakt). Ruim 2I\% van de Rijksambtenaren met versoberde pensioenrechten denkt met deeltijdpensioen te gaan, tegenover slechts $16,6 \%$ van de werkenden die nog met FPU kunnen. Dit duidt er op dat de werknemers in deze sector de deeltijdpensionering inderdaad willen gebruiken om de relatief sterke daling in hun pensioenuitkering te compenseren. De voorgaande tabellen maakten al duidelijk dat werknemers in het Rijk een relatief sterkere daling in hun pensioenuitkering verwachten en dat zij ook verwachten daarom langer door te moeten werken. Deeltijdpensionering is in deze context een bruikbaar middel om de verloren vrije tijd gedeeltelijk te compenseren tot aan het moment van de definitieve arbeidsmarktuittrede.

Voor de sectoren Provincies en Waterschappen en UMC's vinden we daarentegen een zwak significant negatief effect op de plannen om met deeltijdpensioen te gaan. Interessant is dat de werknemers met versoberde pensioenrechten in deze sectoren niet eerder denken uit te treden terwijl hun verwachte pensioenuitkering wel significant lager is dan voor degenen die in 1949 geboren zijn. In tegenstelling tot de werkenden bij het Rijk lijkt het er dus op dat de werknemers bij de Provincies en Waterschappenen en UMC's er dus voor kiezen om ondanks de versobering van hun pensioenrechten hun pensioneringsplannen te handhaven en van deeltijdpensionering afzien om de daling in hun pensioen te beperken. 
Tabel 2.4

Impact versobering pensioenrechten op verwachte deeltijdpensionering in 2009 per sector

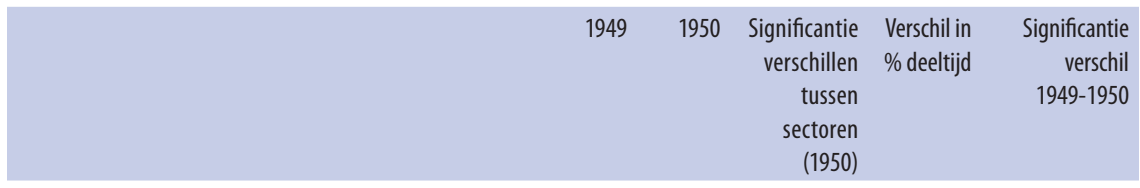

Bent u op dit opgenblik met deeltijdpensioen of bent $u$

van plan om met deeltijdpensioen te gaan?

Rijk

Defensie burger

Gemeenten

Provincies en Waterschappen

Primair Onderwijs

Voortgezet Onderwijs

Beroeps en volwasseneneducatie

Hoger beroepsonderwijs

Wetenschappelijk onderwijs

Universitair medische centra

Water, energie- en nutsbedrijven

Overig

$\begin{array}{rrrr}16,6 & 21,0 & & 4,4 \\ 12,1 & 16,4 & & 4,3 \\ 17,1 & 18,5 & & 1,4 \\ 25,9 & 15,2 & * * & -10,7 \\ 27,1 & 33,5 & & 6,4 \\ 29,6 & 35,1 & & 5,5 \\ 21,8 & 18,6 & & -3,2 \\ 21,6 & 23,3 & & 1,7 \\ 18,5 & 14,2 & * & -4,3 \\ 24,6 & 14,3 & * & -10,3 \\ 9,9 & 8,2 & * * * & -1,7 \\ 20,2 & 25,0 & & 4.8\end{array}$

$17,4 \quad 18,3$

0,9

*** significant op 1\%-niveau, ** significant op 5\%-niveau, * significant op $10 \%$-niveau. De significantie van de verschillen tussen de sectoren is bepaald door middel van een OLS regressie vergelijking waarin dummy variabelen zijn opgenomen voor elke sector (Rijk is de referentiecategorie).

\section{Repareren werknemers hun pensioenrechten?}

Waarom hebben de werknemers met verminderde pensioenrechten de leeftijd waarop ze met pensioen denken te gaan in de periode 2006-2009 naar beneden bijgesteld? Hiervoor bestaan twee mogelijke verklaringen. Allereerst kan iemand besluiten om toch met pensioen te gaan op de leeftijd waarop hij voor de verandering van het pensioenstelsel met pensioen dacht te gaan, met als gevolg dat hij een lagere pensioenuitkering moet accepteren. Ook kan iemand besluiten om meer te gaan sparen om de schok in het pensioenrechten gedeeltelijk op te vangen waardoor deze weer eerder met pensioen kan gaan.

Tabel 2.5 laat zien dat mensen met verminderde pensioenrechten inderdaad meer zijn gaan sparen voor hun pensioen door middel van de levensloopregeling. Bij de werknemers die geboren zijn in 1950 is de participatie in de levensloopregeling ruim 
Ook hebben we onderzocht in hoeverre mensen privé zijn gaan sparen om het door de afschaffing van de FPU ontstane daling in hun pensioenrechten te dichten. Daarbij maken wij gebruik van de antwoorden op de volgende enquêtevraag.

Als $u$ het saldo van al uw spaarrekeningen, beleggingen en liffrentepolissen voor uw pensioen bij elkaar optelt, hoe hoog is dit saldo dan?

Tabel 2.5 laat zien dat mensen die geboren zijn in 1950 privé meer sparen voor hun pensioen door middel van andere pensioenproducten. Het effect van de versobering van hun pensioen rechten op het spaargedrag is echter veel kleiner dan het effect op de participatie in de levensloopregeling. Bovendient blijkt dat de waarde van het gespaarde bedrag niet significant verschilt van het bedrag dat degenen die in 1949 zijn geboren voor hun pensioen sparen.

Tabel 2.7

Participatie in de levensloopregeling per sector

$\begin{array}{rrrr}1949 \quad 1950 \quad & \text { Significantie } & \text { Verschil in \% } & \text { Significantie } \\ & \text { verschillen } & \text { levensloop } & \text { verschil } \\ & \text { tussen } & 1949-1950 \\ & \text { sectoren } & \\ & (1950) & \end{array}$

\begin{tabular}{|c|c|c|c|c|c|}
\hline Rijk & 4,1 & 11,8 & & 7,7 & $* * *$ \\
\hline Defensie burger & 1,7 & 4,4 & * & 2,7 & \\
\hline Gemeenten & 4,9 & 12,4 & & 7,5 & $* * *$ \\
\hline Provincies en Waterschappen & 6,0 & 12,3 & & 6,3 & \\
\hline Primair Onderwijs & 6,0 & 10,1 & & 4,1 & * \\
\hline Voortgezet Onderwijs & 6,5 & 12,4 & & 5,9 & $* * *$ \\
\hline Beroeps en volwasseneneducatie & 2,3 & 12,3 & & 10,0 & $* * *$ \\
\hline Hoger beroepsonderwijs & 4,0 & 16,9 & & 12,9 & $* * *$ \\
\hline Wetenschappelijk onderwijs & 5,9 & 9,0 & & 3,1 & \\
\hline Universitair medische centra & 5,9 & 25,3 & ** & 19,4 & $* * *$ \\
\hline Water, energie- en nutsbedrijven & 3,3 & 41,1 & $* * *$ & 37,8 & $* * *$ \\
\hline Overig & 6,3 & 11,9 & & 5,6 & \\
\hline Totaal & 4,6 & 14,1 & & 9,5 & $* * *$ \\
\hline
\end{tabular}


Tabel 2.7 laat zien dat de participatie in de levensloopregeling door de afschaffing van de FPU aanzienlijk is toegenomen in de sectoren Water, Energie- en Nutsbedrijven, UMC's, het Hoger Beroepsonderwijs en bij de Beroeps- en Volwasseneneducatie waardoor in deze sectoren de participatie in de levensloop ook significant hoger ligt dan in andere sectoren. Ruim $4 \mathrm{I} \%$, van de werknemers met versoberde pensioenrechten in de Water, Energie- en Nutsbedrijven geven aan dat zij participeren in de levensloopregeling.7 Bij de UMC's is dit ruim 25,3\%. Daarentegen blijft de participatie betrekkelijk laag onder de werkenden bij Defensie $(4,4 \%)$.

7. Relevant hierbij is dat de cijfers in deze tabel gebaseerd zijn op de surveyvraag in hoeverre mensen gebruik maken of gebruik gaan maken van de levensloopregeling. De participatie in de levensloopregeling kan daardoor iets hoger liggen dan feitelijk wordt waargenomen. Bovendien kunnen werknemers bij verschillende organisaties verlof sparen in het kader van de levensloopregeling waardoor het moeilijk is om een gedetailleerd beeld te krijgen van de feitelijke participatie. 


\section{Financiële prikkels en duurzame inzetbaarheid}

Als beleidsinstrument voor het verhogen van de arbeidsparticipatie is de vervanging van de FPU door het ABP Keuzepensioen slechts weinig effectief geweest. ${ }^{8}$ Echter, de verandering in het pensioenstelsel heeft mogelijk ook consequenties voor de productiviteit van oudere werknemers. Met het oog hierop zijn er in de enquêtes van 2008 en 2009 drie vragen opgenomen die als een goede indicator kunnen dienen voor het plezier in het werk en de productiviteit van werknemers. Daarbij gaat het om:

- de algemene tevredenheid met het leven

- de baantevredenheid

- de mentale gezondheid.

Alle drie indicatoren geven een beeld van de inzet die iemand wil en kan leveren in zijn werk.

De eerste indicator meet de algemene tevredenheid in het leven en is gebaseerd op het antwoord op de volgende vraag:

- Hoe tevreden bent u met uw leven in het algemeen?

De tweede indicator meet de algemene baantevredenheid:

- Hoe tevreden bent u met uw werk?

Beide vragen moesten beantwoord worden op een II-punts schaal tussen o (zeer ontevreden) tot en met Io (zeer tevreden).

De derde indicator voor iemands inzetbaarheid is de mentale gezondheid van werknemers. Een studie van Van Loo c.s. ${ }^{9}$ laat zien dat werknemers in de overheid en het onderwijs vooral psychisch zwaar werk doen, waarbij er vaak sprake is van stress. Het

8. Zie ook Euwals, R., De Mooij, R., en D. Van Vuuren, Rethinking Retirement, Bijzondere Publicatie No. 8o, CPB, Den Haag.

9. Van Loo, J., De Grip, A., en R. Montizaan (2005), Active Aging by Overheid en Onderwijs, ABP, Heerlen. 
is daarom belangrijk om te kijken naar het effect van de verandering in het pensioenstelsel op de psychische gezondheid. Als maatstaf voor de mentale gezondheid wordt een depressiviteitindicator gebruikt die gebaseerd is op de zogenaamde CES-D8 vragenlijst. ${ }^{10}$ Dit is een veel gebruikte index voor het bepalen van iemands mentale gesteldheid waarvan in de praktijk is aangetoond dat deze goed in staat is om psychometrische kenmerken vast te stellen. ${ }^{\text {II }}$

Tabel 3.I toont de resultaten van regressieanalyses waarin het effect van het verschil in pensioenrechten als gevolg van de versoberde pensioenrechten op de drie productiviteitsindicatoren is geschat. De tabel laat zien dat er een significant negatief effect is van de vervanging van de FPU door het ABP Keuzepensioen op de algemene tevredenheid met het leven. Dit betekent dat mensen die geconfronteerd werden met de versobering van hun pensioenrechten dus minder tevreden zijn met hun leven. Het effect lijkt in eerste instantie vrij klein. Echter, als men het vergelijkt met de impact van het salaris op de algemene tevredenheid, dan blijkt dat de impact van de versobering van de pensioenrechten overeenkomt met het verdienen van een jaarsalaris dat maar liefst ruim 33.000 euro lager is (berekening gebaseerd op de coëfficiënt van het salaris dat is opgenomen als controlevariabele in de regressie-analyse).

Tabel 3.1

Impact versobering pensioenrechten op inzetbaarheid werkenden

\begin{tabular}{|c|c|c|}
\hline Algemene tevredenheid met leven & $-0,132^{* *}$ & $(0,054)$ \\
\hline Algemene tevredenheid met baan & $-0,228^{* *}$ & $(0,088)$ \\
\hline Depressiviteit & $0,028^{* * *}$ & $(0,009)$ \\
\hline
\end{tabular}

De tabel laat ook zien dat niet alleen de algemene tevredenheid is afgenomen, maar dat werknemers die geboren zijn in 1950 ook minder tevreden zijn met hun baan. Zoals verwacht mag worden is dit effect nog groter dan het effect op de algemene tevredenheid met het leven. De versobering van de pensioenrechten is immers direct gerelateerd aan de periode dat iemand nog moet blijven werken. Uit de tabel blijkt

Io. De CES-D-8 wordt onder andere gebruikt in de Amerikaanse Health and Retirement Study. Respondenten kunnen aangeven of zij het eens zijn met acht stellingen over hun mentale gezondheid of niet. Mensen worden als depressief aangemerkt als zij een score hebben van 4 of hoger.

II. Bouma, J., Ranchor, A.V., Sanderdam, R., en E. van Sonderen (1995), Het meten van symptomen van depressie met de CES-D: Een Handleiding, Noordelijk Centrum voor Gezondheidsvraagstukken, Rijksuniversiteit Grondingen. Fonda, S., en R. Herzog (2004), Documentation of Physical Functioning Measured in the HRS. 
ook dat mensen die geboren zijn in 1950 vaker depressief zijn. ${ }^{\mathrm{I2}}$ Onder degenen met versoberde pensioenrechten is het percentage mensen dat depressief is ongeveer $3 \%$-punt hoger. Dat wil zeggen dat het aantal mensen dat depressief is en geboren is in 1950 bijna is verdubbeld. Dit resultaat is opvallend, aangezien deze mensen gemiddeld een jaar jonger zijn dan degenen die in 1949 zijn geboren en er doorgaans een positieve relatie wordt gevonden tussen leeftijd en depressiviteit. ${ }^{13}$ Interessant daarbij is dat afzonderlijke regressies op de individuele sectoren laten zien dat de versobering van de pensioenrechten een bijzonder grote impact heeft op de mentale gezondheid van werkenden in de sector Beroeps- en Volwasseneneducatie. In deze sector is het percentage mensen dat depressief is ruim 6\%-punt hoger onder degenen die geboren zijn in 1950 dan onder degenen die geboren zijn in 1949.

Tabel 3.2

Is de impact van de versobering van de pensioenrechten duurzaam of slechts tijdelijk?

Impact afschaffing FPU Standaardfout

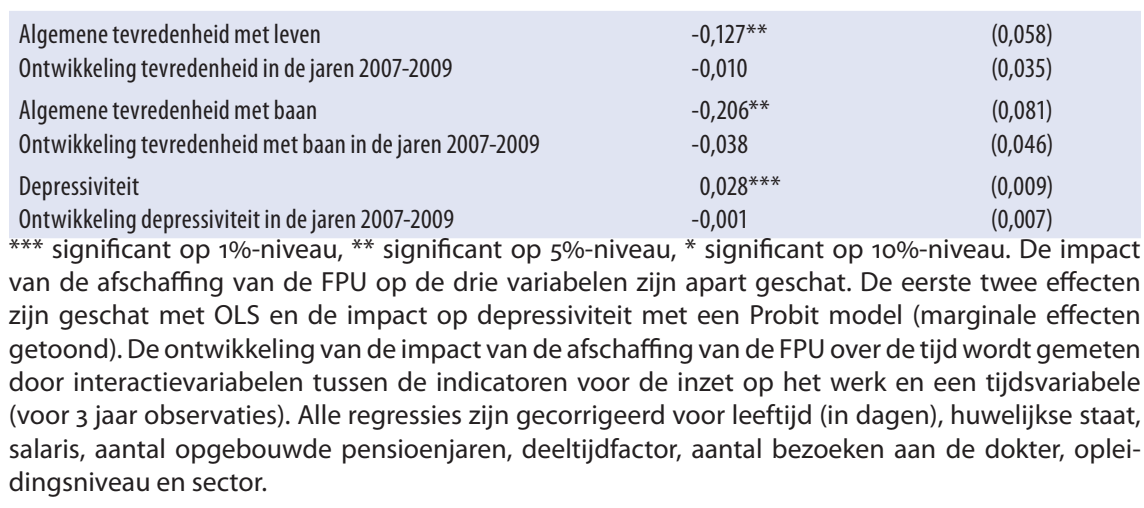

De daling van de inzet op het werk kan grote consequenties hebben op de productiviteit van oudere werknemers. Voor de werkgever kan deze daling in de productiviteit zeer schadelijk zijn wanneer de toegenomen ontevredenheid met het werk vanwege de vervanging van de FPU door het ABP Keuzepensioen na enige tijd niet verdwijnt. Tabel 3.2 geeft een overzicht van de resultaten van een analyse van het effect van de versoberde pensioenrechten op de verschillende indicatoren voor de inzet op het werk. Daarbij wordt ook gekeken of het effect na verloop van tijd afneemt. Uit de tabel blijkt dat er geen sprake is van een afname van het effect na verloop van tijd. Hieruit kan worden geconcludeerd dat de negatieve impact van de versoberde pensioenrechten op de tevredenheid van oudere werknemers een duurzaam effect lijkt te

I2. We hebben ook geanalyseerd in hoeverre de groep die net niet in 1949 is geboren wellicht minder depressief is dan de groep geboren in 1950 vanwege een mogelijk opluchtingseffect. Dit blijkt niet het geval te zijn.

I3. Fonda, S., Wallace, R.B., en R. Herzog (200I), Changes in Driving Patterns and Worsening Depressive Symptoms Among Older Adults, Journal of Gerontology, Vol. 65. 
HOOFDSTUK 3

zijn. Hetzelfde geldt voor de toename van het aantal mensen dat als gevolg van de afschaffing van de FPU kampt met depressieverschijnselen. 


\section{Active aging in de sector Overheid en Onderwijs}

In hoeverre hebben werkgevers in de Overheidssector en het Onderwijs al een active aging beleid ontwikkeld om de mensen met versoberde pensioenrechten intrinsiek te motiveren om langer door te werken? Met andere woorden, zijn werkgevers in hun personeelsbeleid meer aandacht gaan geven aan diegenen die langer moeten gaan doorwerken? Om deze vraag te beantwoorden is in de enquêtes ook een aantal vragen gesteld over het personeelsbeleid van de organisatie waarin iemand werkzaam is.

Allereerst is aan de werknemers gevraagd om het personeelsbeleid van hun werkgever in het algemeen te beoordelen en aan te geven in hoeverre hun werkgever zich meer is gaan inzetten om hen langer aan het werk te houden. Figuur 4.I laat zien dat veel werknemers negatief oordelen over het personeelsbeleid in hun organisatie. Slechts $24 \%$ van alle werknemers vindt dat hun werkgever in het algemeen een goed personeelsbeleid voert, terwijl $39 \%$ zelfs vindt dat de organisatie waarin ze werkzaam zijn een slecht tot zeer slecht personeelsbeleid voert. Opvallend is eveneens dat slechts II\% van alle werknemers aangeeft dat hun werkgever zich meer is gaan inzetten om hen langer aan het werk te houden, terwijl ruim 58\% van alle werknemers aangeeft dat dit (volstrekt) niet het geval is. Dit negatieve oordeel over het gevoerde personeelsbeleid verschilt ook niet significant tussen de werknemers die nog met FPU kunnen en degenen met versoberde pensioenrechten. Hieruit blijkt dat werkgevers in de Overheid en het Onderwijs nog niet succesvol zijn om het oudere personeel dat is geconfronteerd met een verslechtering van hun pensioenrechten, meer intrinsiek te motiveren voor hun werk door middel van een goed active aging beleid.

Tabel 4.I laat zien dat in alle sectoren de meeste oudere werknemers niet tevreden zijn over het personeelsbeleid van de organisatie waar zij werkzaam zijn. In geen van de sectoren komt het percentage werknemers dat positief is over het gevoerde personeelsbeleid boven de 40\%. Vooral de sectoren Defensie Burger, Gemeenten, Beroeps en Volwasseneneducatie en het Wetenschappelijk Onderwijs scoren op dit punt slecht. Werknemers in het Primair Onderwijs en in de Water, Energie en Nutsbedrijven oordelen iets positiever, maar ook in deze sectoren blijft de score laag. 


\section{Figuur 4.1}

Percentage werkenden dat een positief oordeel geeft over het personeels- en active aging beleid van de organisatie waarin ze werkzaam zijn, 2009

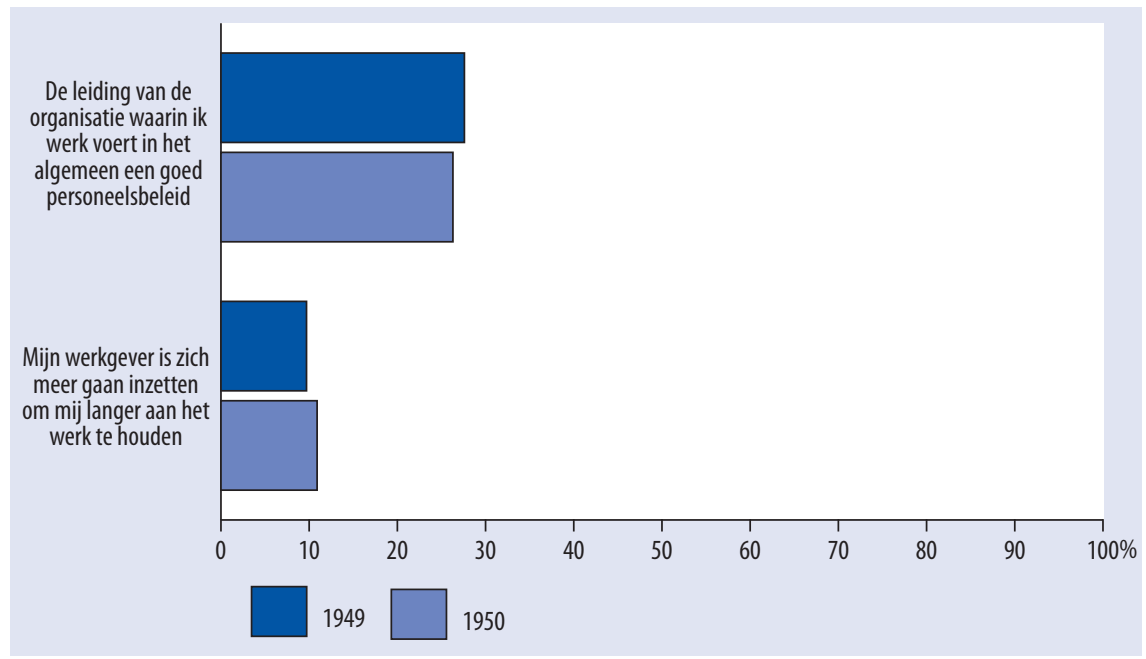

Tabel 4.1

Tevredenheid over het personeelsbeleid per sector

$\begin{array}{rrrr}1949 \quad 1950 & \text { Significantie } & \text { Verschil in \% } & \text { Significantie } \\ \text { verschillen } & \text { verschil } \\ & \text { tussen } & 1949-1950 \\ & \text { sectoren } & \\ & (1950) & \end{array}$

\begin{tabular}{|c|c|c|c|c|c|}
\hline Rijk & 24,9 & 28,4 & & 3,5 & \\
\hline Defensie burger & 13,0 & 19,8 & * & 6,8 & \\
\hline Gemeenten & 25,7 & 22,0 & $* * *$ & $-3,7$ & \\
\hline Provincies en Waterschappen & 36,9 & 33,3 & & $-3,6$ & \\
\hline Primair Onderwijs & 42,6 & 35,4 & $* *$ & $-7,2$ & * \\
\hline Voortgezet Onderwijs & 28,4 & 23,9 & & $-4,5$ & \\
\hline Beroeps en volwasseneneducatie & 16,0 & 14,6 & $* * *$ & $-1,4$ & \\
\hline Hoger beroepsonderwijs & 26,2 & 24,8 & & $-1,4$ & \\
\hline Wetenschappelijk onderwijs & 32,3 & 19,0 & $* *$ & $-13,3$ & $* * *$ \\
\hline Universitair medische centra & 24,6 & 31,1 & & 6,5 & \\
\hline Water, energie- en nutsbedrijven & 28,1 & 36,1 & * & 8,0 & \\
\hline Overig & 20,7 & 30,8 & & 10,1 & \\
\hline Totaal & 27,6 & 26,3 & & $-1,3$ & \\
\hline
\end{tabular}


Tevens is het opvallend dat de werknemers met versoberde pensioenrechten in het Primair en Wetenschappelijk onderwijs significant slechter oordelen over het personeelsbeleid dan diegenen die geboren zijn in 1949. Dit duidt er op dat in deze twee sectoren het huidige personeelsbeleid nog sterker op gespannen voet staat met de nieuwe situatie die is ontstaan als gevolg van de versoberde pensioenrechten dan in de andere sectoren.

Tabel 4.2 bevestigt het beeld uit Tabel 4.I. In alle sectoren geeft maar een kleine groep werknemers aan dat hun werkgever zich meer is gaan inzetten om hen langer aan het werk te houden. Ook hier scoren Beroeps- en Volwasseneneducatie en het Wetenschappelijk Onderwijs bijzonder slecht. Ook de werknemers van Gemeenten en Provincies en Waterschappen oordelen minder gunstig over de inzet van hun werkgever.

Wel blijkt dat de werkgevers in de sectoren Rijk, UMC's en Water, Energie en Nutsbedrijven zich sterker zijn gaan inzetten om hun oudere werknemers met versoberde pensioenrechten langer in dienst te houden.

\section{Tabel 4.2}

Inzet werkgever om werknemers langer in dienst te houden per sector

$\begin{array}{rrrr}1949 \quad 1950 & \text { Significantie } & \text { Verschil in \% } & \text { Significantie } \\ & \text { verschillen } & \text { verschil } \\ & \text { tussen } & 1949-1950 \\ & \text { sectoren } & \\ & (1950) & \end{array}$

\begin{tabular}{|c|c|c|c|c|c|}
\hline Rijk & 9,4 & 12,9 & & 3,5 & * \\
\hline Defensie burger & 11,1 & 8,1 & & $-3,0$ & \\
\hline Gemeenten & 8,4 & 8,1 & $* * *$ & $-0,3$ & \\
\hline Provincies en Waterschappen & 8,3 & 9,1 & * & 0,8 & \\
\hline Primair Onderwijs & 11,1 & 13,8 & & 2,7 & \\
\hline Voortgezet Onderwijs & 9,8 & 11,4 & & 1,6 & \\
\hline Beroeps en volwasseneneducatie & 7,2 & 7,0 & $* *$ & $-0,2$ & \\
\hline Hoger beroepsonderwijs & 10,2 & 10,4 & & 0,2 & \\
\hline Wetenschappelijk onderwijs & 9,4 & 7,1 & * & $-2,3$ & \\
\hline Universitair medische centra & 6,1 & 18,3 & & 12,2 & ** \\
\hline Water, energie- en nutsbedrijven & 10,9 & 17,8 & * & 6,9 & * \\
\hline Overig & 19,5 & 4,3 & & $-15,2$ & $* * *$ \\
\hline $\begin{array}{l}\text { Totaal } \\
* * * \text { significant } 00 \text { 10-nive }\end{array}$ & 9,7 & 10,9 & & 1,2 & \\
\hline
\end{tabular}


Figuur 4.2 geeft een beeld van de inzet van drie belangrijke faciliteiten die onder het personeels- en active aging beleid vallen. Twee belangrijke onderdelen van het active aging beleid zijn:

- de mogelijkheden tot aanpassing van de taakbelasting en

- het werken in deeltijd

Een ander waardevol onderdeel van het personeels- en ouderenbeleid is het voeren van het geven van feedback over iemands persoonlijke ontwikkeling en doorgroeimogelijkheden.

Van Loo c.s. (2005) hebben in hun studie naar het active aging beleid in de publieke sector aangetoond dat werknemers dit de belangrijkste beleidsinstrumenten vinden om hen te stimuleren om langer door te werken. Uit de figuur blijkt echter dat werkgevers vaak niet bereid zijn om de taakbelasting van oudere werknemers aan te passen. Slechts $39 \%$ van alle werknemers geeft aan dat hun werkgever hiertoe bereid is. Wat betreft de mogelijkheid om in deeltijd te werken, oordelen werknemers duidelijker positiever. Iets meer dan $63 \%$ van de respondenten heeft een werkgever die ze de mogelijkheid biedt om in deeltijd te gaan werken. Werknemers die geboren zijn in I950 zijn op dit punt echter iets negatiever (61,8\%). Dit verschil is significant.

\section{Figuur 4.2}

Percentage werknemers dat aangeeft dat hun organisatie faciliteiten van personeels- en active aging beleid aanbiedt, 2009

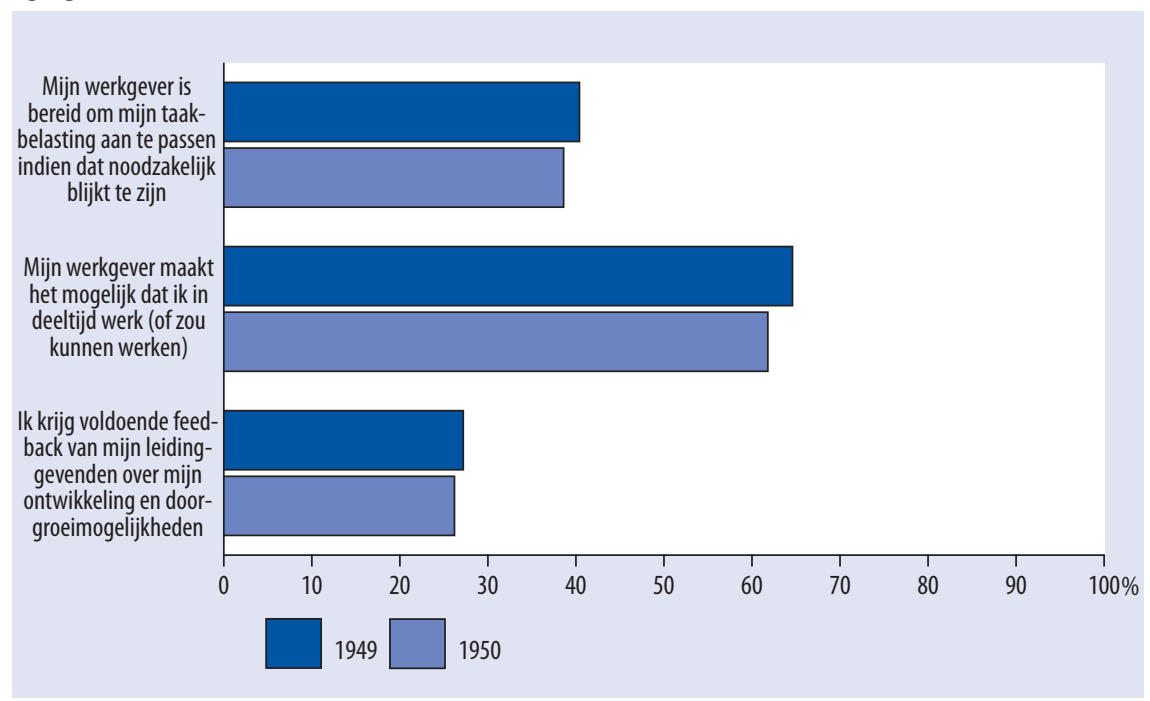

De meeste werknemers geven aan dat zij ontevreden zijn over de feedback die zij krijgen. Slechts $24 \%$ geeft aan dat hun leidinggevende hen voldoende feedback geeft over hun ontwikkeling en doorgroeimogelijkheden. Er blijkt eveneens geen verschil te zijn in het oordeel over de feedback van de leidinggevenden tussen werknemers 
geboren in 1949 en 1950. Dit betekent dat de werknemers die geboren zijn in 1950 dus niet ervaren dat zij meer feedback krijgen op hun ontwikkeling en doorgroeimogelijkheden, ondanks het feit dat zij langer door zullen moeten werken.

Uit Tabel 4.3 blijkt dat werknemers in de sector Provincies en Waterschappen duidelijker positiever zijn over de bereidheid van hun werkgever om de taakbelasting aan te passen. Ruim 53\% van alle werknemers in deze sector die geboren zijn in 1950 oordeelt hierover positief. Vooral de Gemeenten en de Beroeps- en Volwasseneneducatie blijven daar sterk bij achter. In de laatstgenoemde sector oordeelt slechts $31 \%$ van de werknemers positief over de bereidheid van hun werkgever om de taakbelasting aan te passen. Eveneens opvallend is dat er geen verschillen worden weergenomen in de percepties van de werknemers die geboren zijn in 1949 of 1950 . Dit geeft een verdere indicatie van dat werkgevers de veranderingen in het pensioensysteem nog niet in voldoende mate accommoderen.

\section{Tabel 4.3}

Bereidheid tot aanpassing taakbelasting per sector

$\begin{array}{rrrr}1949 \quad 1950 \quad \begin{array}{r}\text { Significantie } \\ \text { verschillen }\end{array} & \text { Verschil in \% } & \text { Significantie } \\ & \text { verschil } \\ & \text { tussen } & 1949-1950 \\ & \text { sectoren } & \\ & (1950) & \end{array}$

$\begin{array}{lllll}\text { Rijk } & 44,1 & 40,1 & & -4,0 \\ \text { Defensie burger } & 30,2 & 38,4 & & 8,2 \\ \text { Gemeenten } & 38,3 & 34,9 & * & -3,4 \\ \text { Provincies en Waterschappen } & 54,5 & 53,1 & * * & -1,4 \\ \text { Primair Onderwijs } & 40,0 & 42,3 & & 2,3 \\ \text { Voortgezet Onderwijs } & 44,3 & 39,6 & & -4,7 \\ \text { Beroeps en volwasseneneducatie } & 29,3 & 31,0 & * * & 1,7 \\ \text { Hoger beroepsonderwijs } & 39,0 & 45,6 & & 6,6 \\ \text { Wetenschappelijk onderwijs } & 41,7 & 35,4 & & -6,3 \\ \text { Universitair medische centra } & 43,1 & 33,3 & & -9,8 \\ \text { Water, energie- en nutsbedrijven } & 42,6 & 43,0 & & 0,4 \\ \text { Overig } & 31,0 & 39,3 & & 8,3\end{array}$

Totaal $\quad 40,4 \quad 38,6 \quad-1,8$

*** significant op 1\%-niveau, ** significant op 5\%-niveau, * significant op 10\%-niveau. De significantie van de verschillen tussen de sectoren is bepaald door middel van een OLS regressie vergelijking waarin dummy variabelen zijn opgenomen voor elke sector (Rijk is de referentiecategorie).

Uit Tabel 4.4 blijkt dat er tussen de sectoren grote verschillen zijn in de mogelijkheid om in deeltijd te werken. Werknemers in de sectoren Rijk, Primair Onderwijs 
en Provincies en Waterschappen geven vaker aan dat hun werkgever de mogelijkheid biedt om in deeltijd te werken. De andere sectoren scoren op dit punt significant lager. De sectoren waarin het minst de mogelijkheid wordt geboden om in deeltijd te werken zijn de Gemeenten, UMC's en Defensie Burger. Interessant daarbij is dat het I950 cohort in de Gemeenten en de UMC's significant slechter oordeelt over de mogelijkheid om in deeltijd te werken ten opzichte van het 1949 cohort. Bij de UMC's is dit beleid consistent met het lage percentage werknemers dat met deeltijdpensioen denkt te gaan. Het is de vraag in hoeverre in deze sector een ontmoedigingsbeleid wordt gevoerd tegen deeltijdpensionering van diegenen met versoberde pensioenrechten.

Tabel 4.4

Mogelijk maken van deeltijdwerk per sector

$\begin{array}{rrr}1949 \quad 1950 \quad \begin{array}{r}\text { Significantie } \\ \text { verschillen }\end{array} & \text { Verschil in \% } & \text { Significantie } \\ \text { tussen } & \text { verschil } \\ \text { sectoren } & 1949-1950 \\ (1950) & \end{array}$

\begin{tabular}{|c|c|c|c|c|c|}
\hline Rijk & 75,6 & 74,1 & & $-1,5$ & \\
\hline Defensie burger & 48,1 & 51,7 & $* * *$ & 3,6 & \\
\hline Gemeenten & 54,7 & 48,3 & $* * *$ & $-6,4$ & ** \\
\hline Provincies en Waterschappen & 76,6 & 67,7 & & $-8,9$ & \\
\hline Primair Onderwijs & 69,5 & 70,4 & & 0,9 & \\
\hline Voortgezet Onderwijs & 66,1 & 67,2 & $* *$ & 1,1 & \\
\hline Beroeps en volwasseneneducatie & 56,3 & 55,1 & $* * *$ & $-1,2$ & \\
\hline Hoger beroepsonderwijs & 66,3 & 61,6 & $* * *$ & $-4,7$ & \\
\hline Wetenschappelijk onderwijs & 61,1 & 53,2 & $* * *$ & $-7,9$ & \\
\hline Universitair medische centra & 65,6 & 49,5 & $* * *$ & $-16,1$ & ** \\
\hline Water, energie- en nutsbedrijven & 54,0 & 59,5 & $* * *$ & 5,5 & \\
\hline Overig & 52,9 & 53,8 & ** & 0,9 & \\
\hline Totaal & 64,6 & 61,8 & & $-2,8$ & \\
\hline
\end{tabular}

Uit Tabel 4.5 blijkt dat er eveneens tussen de sectoren grote verschillen zijn in de feedback die werknemers krijgen over hun persoonlijke ontwikkeling van hun directe leidinggevende. De Provincies en Waterschappen, het Rijk en de Water, Energie en Nutsbedrijven scoren beter op dit punt dan de andere sectoren. Daarbij dient echter wel te worden opgemerkt dat ook in deze sectoren maar een kleine groep werknemers positief oordeelt over de feedback die zij krijgen. In de sectoren Gemeenten, Primair Onderwijs, Voortgezet Onderwijs, Beroeps- en Volwasseneneducatie en het 
Wetenschappelijk Onderwijs wordt vaker negatief geoordeeld door de werknemers over de feedback die zij krijgen van hun leidinggevende. Echter, in deze sectoren zijn de doorgroeimogelijkheden, zeker ook op oudere leeftijd, doorgaans ook beperkt.

Tabel 4.5

Feedback van leidinggevenden op persoonlijke ontwikkeling per sector

$\begin{array}{rrrr}1949 \quad 1950 \quad \text { Significantie } & \text { Verschil in \% } & \text { Significantie } \\ \text { verschillen } & \text { verschil } \\ & \text { tussen } & 1949-1950 \\ & \text { sectoren } \\ & (1950) & \end{array}$

\begin{tabular}{|c|c|c|c|c|c|}
\hline Rijk & 29,0 & 33,9 & & 4,9 & * \\
\hline Defensie burger & 26,4 & 25,6 & & $-0,8$ & \\
\hline Gemeenten & 28,0 & 28,4 & $* *$ & 0,4 & \\
\hline Provincies en Waterschappen & 30,6 & 35,3 & & 4,7 & \\
\hline Primair Onderwijs & 32,3 & 28,2 & * & $-4,1$ & \\
\hline Voortgezet Onderwijs & 23,2 & 25,3 & $* * *$ & 2,1 & \\
\hline Beroeps en volwasseneneducatie & 18,8 & 17,4 & $* * *$ & $-1,4$ & \\
\hline Hoger beroepsonderwijs & 28,8 & 27,2 & & $-1,6$ & \\
\hline Wetenschappelijk onderwijs & 29,4 & 19,2 & $* *$ & $-10,2$ & * \\
\hline Universitair medische centra & 20,0 & 29,3 & & 9,3 & \\
\hline Water, energie- en nutsbedrijven & 28,8 & 31,6 & & 2,8 & \\
\hline Overig & 18,3 & 26,6 & & 8,3 & \\
\hline Totaal & 27,2 & 26,1 & & $-1,0$ & \\
\hline
\end{tabular}

Bij het Rijk oordelen de werknemers die vallen onder het ABP Keuzepensioen iets beter over de feedback die zij krijgen dan degenen die nog met FPU kunnen. Werknemers die geboren zijn in 1950 en werken in het Wetenschappelijk onderwijs oordelen daarentegen beduidend slechter dan degenen die geboren zijn in 1949.

Een andere belangrijke faciliteit die kan bijdragen tot het verhogen van de productiviteit van werkenden is de trainingsparticipatie. Van Loo c.s. (2005) hebben reeds aangetoond dat trainingsparticipatie het plezier in het werk kan verhogen, wat een positief effect zal hebben op de motivatie op het werk. Ook zal de training de kennis en/of vaardigheden van werkenden vergroten, waardoor de productiviteit toeneemt.

De Overheidssector en het Onderwijs scoort van oudsher wat betreft de trainingsparticipatie beter dan de private sector. $56 \%$ van alle werknemers die geboren zijn in 
1949 of 1950 hebben in 2007 een training gevolgd. De trainingsparticipatie is in de jaren daarna constant gebleven, hoewel er in 2008 sprake was van een kleine daling in de trainingsdeelname. Deze daling is waarschijnlijk deels het gevolg van de weerslag die de economische crisis had op de trainingsbudgetten in de Overheidssector en het Onderwijs.

De menselijke kapitaaltheorie voorspelt dat het meest efficiënte trainingsbeleid bestaat uit het zo vroeg mogelijk trainen van werknemers die langer door moeten werken. In dat geval hebben zijzelf en hun werkgever in hun resterende carrière het meeste voordeel van de training. Daarnaast kan worden verwacht dat uitsluitend grote organisaties hun trainingsbeleid kunnen aanpassen, aangezien de vaste kosten van (extra) trainingscursussen hoog zijn en er voldoende werknemers moeten zijn die geen recht meer hebben op FPU en daarom extra bijscholing nodig hebben.

In twee aparte analyses hebben we onderzocht of de vervanging van de FPU door het ABP Keuzepensioen in de periode 2007-2009 de trainingsparticipatie van werknemers in grote en kleine organisaties in de Overheidssector en het onderwijs heeft beïnvloed. Zoals verwacht vinden wij geen effect van de afschaffing van de FPU op het trainingsbeleid van kleine organisaties. Echter, de grote organisaties met meer dan I.000 werknemers lijken wel een efficiënt trainingsbeleid te voeren waarin er aandacht is voor de noodzaak om degenen die in 1950 geboren zijn langer productief inzetbaar te houden. Tabel 4.6 laat zien dat in deze grote organisaties de trainingsparticipatie van de mensen die geen recht meer hebben op de FPU in 2007 ruim 8\%-punt hoger is dan de trainingsdeelname van degenen die wel nog recht hebben op FPU. Aangezien het overgrote deel van alle trainingen en cursussen in de publieke sector door de werkgever wordt betaald, betekent dit dat grote organisaties dus extra hebben geïnvesteerd in hun werknemers die langer zullen moeten doorwerken. Ook laat de tabel zien dat de werkgevers van deze organisaties snel hebben gereageerd door werknemers direct na de schok in het pensioenstelsel te trainen, terwijl er in 2008 en 2009 geen significant verschil meer is in de trainingsparticipatie.

Tabel 4.6

Trainingsparticipatie

$\begin{array}{ll}\text { Trainingsparticipatie 2007-2009 (grootte organisaties) } & \\ & \text { Impact afschaffing Standaardfout } \\ \text { FPU }\end{array}$

\begin{tabular}{|c|c|c|}
\hline 2007 & $0,081^{* * *}$ & $(0,034)$ \\
\hline 2008 & $-0,005$ & $(0,041)$ \\
\hline 2009 & $-0,010$ & $(0,038)$ \\
\hline
\end{tabular}




\section{Financiële prikkels en pensioengedrag van de partner}

Enkele studies van Blau (1997, 1998) en Coile (2004)I4 tonen aan dat echtparen waarvan beide partners werken hun uittredebesluit gezamenlijk nemen. Indien echtparen besluiten tegelijk met pensioen te gaan, dan zal de vervanging van de FPU door het ABP Keuzepensioen mogelijk ook effect hebben op het tijdstip waarop iemands partner met pensioen gaat.

Om dit te onderzoeken maken we gebruik van een aantal vragen die in de enquête van 2009 zijn gesteld. De meest interessante vragen hebben betrekking op de verwachte pensioenleeftijd van de partner en het geboortejaar van de partner. De informatie op basis van de tweede vraag is gehercodeerd tot een variabele die aangeeft of de partner voor 1950 of na 1949 is geboren. Dit betekent dat deze variabele een indicatie geeft van de pensioenrechten van de partner. Immers, de afschaffing van de FPU was het gevolg van het afschaffen van de fiscale aftrek van het prepensioen in 2006. Dit betekent dat ook werknemers in andere sectoren die geboren zijn in 1950 of later, verminderde pensioenrechten hebben.

Tabel 5.I laat het effect zien van de versoberde pensioenrechten op de pensioenleeftijd van de partners van de werknemers in onze steekproef. We vinden dat de partners van de mannen die in 1950 geboren zijn hun pensioen eveneens met ongeveer drie maanden uitstellen. Dit resultaat duidt erop dat echtparen samen met pensioen willen en bij versobering van het pensioen van één van de partners besluiten om gezamenlijk hun pensioen uit te stellen.

I4. Blau, D.M., (1997), Social security and the labor supply of older married couples, Journal of Labor Economics 4, 373-4I8. Blau, D.M., (I998), Labor Force Dynamics of Older Married Couples, Journal of Labor Economics 16, 595-629. Coile, C., (2004), Retirement Incentives and Couples' Retirement Decisions, Topics in Economic Analysis \& Policy 4. 
Tabel 5.1

Effect afschaffing FPU op de pensioenleeftijd van de partner

\begin{tabular}{|c|c|c|}
\hline Pensioenleeftijd & Impact afschaffing FPU & Standaardfout \\
\hline $\begin{array}{l}\text { Effect eigen versoberde } \\
\text { pensioenrechten }\end{array}$ & $0,413^{* * *}$ & $(0,092)$ \\
\hline $\begin{array}{l}\text { Effect versobering pensioenrechten } \\
\text { van partner }\end{array}$ & $0,209^{* * *}$ & $(0,057)$ \\
\hline
\end{tabular}

Andersom is er ook een effect van de pensioenrechten van de partner op het pensioengedrag op de mannen in onze steekproef (Tabel 5.2). Als werknemers geboren zijn in I950, dan verwachten zij drie maanden langer door te werken, maar als hun partner ook geboren is in 1950 of later, dan verwachten zij nog eens twee maanden extra langer door te moeten werken. Interessant daarbij is dat de mannen in onze steekproef aangeven dat zij bij hun beslissing wanneer zij met pensioen gaan iets minder worden beïnvloed door hun partner dan dat hun partner door hen wordt beïnvloed. Dit kan grotendeels worden verklaard vanuit het feit dat alle mannen in onze steekproef fulltime werken en daarom meestal kostwinner zijn en hun partners veelal in deeltijd werken. Hierdoor zal het pensioeninkomen in hun huishouden vooral door hun eigen pensioenrechten worden bepaald.

Tabel 5.2

Effect afschaffing FPU van de partner op de eigen pensioenleeftijd

Impact afschaffing FPU Standaardfout

Effect afschaffing FPU op pensioenleeftijd partner

$0,323^{* *}$

*** significant op 1\%-niveau, ${ }^{* *}$ significant op 5\%-niveau, ${ }^{*}$ significant op $10 \%$-niveau. De OLS regressie is gecorrigeerd voor leeftijd (in dagen), huwelijkse staat, salaris, aantal opgebouwde pensioenjaren, aantal bezoeken aan de dokter, opleidingsniveau en sector. 


\section{Conclusie}

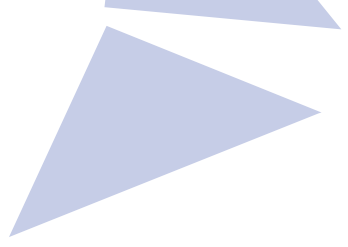

Samenvatting

De effecten van de vergrijzing van de beroepsbevolking zullen de komende jaren steeds meer zichtbaar worden. Vooral in de sector Overheid en Onderwijs zijn er momenteel relatief veel 45-plussers werkzaam. Doordat de Overheid en het Onderwijs een veel sterker vergrijsd personeelsbestand kennen dan de private sector, zal de toekomstige arbeidsmarktuitstroom vanwege pensionering in deze sectoren ook veel groter zijn. Hoewel de economische crisis op de korte termijn de wervingsproblematiek enigszins verlicht, zal de toenemende uitstroom van de na-oorlogse babyboomgeneratie reeds binnenkort al grote gevolgen hebben voor de personeelsvoorziening in deze sector. Verwacht wordt dat de knelpunten in de personeelsvoorziening op de arbeidsmarktsegmenten waarop de sector Overheid en Onderwijs haar personeel werft relatief groot zullen zijn. Het is daarom van groot belang dat de arbeidsmarktparticipatie van oudere werknemers in deze sector wordt gestimuleerd en dat oudere werknemers hun productiviteit behouden. Dit vereist een goed active aging beleid van de werkgevers dat gericht is op de duurzame inzetbaarheid van het oudere personeel en dat al bij jonge cohorten preventief begint om hen te motiveren om langer door te werken en om hun inzet op latere leeftijd te garanderen.

In dit rapport is ingegaan op de vraag in hoeverre de vervanging van de FPU door invoering van het ABP Keuzepensioen een effectief beleidsinstrument is om langer doorwerken te stimuleren. Ook is gekeken naar mogelijke negatieve effecten van deze financiële prikkels op de duurzame inzetbaarheid van oudere werknemers en hoe de gevolgen van de financiële prikkels in de verschillende sectoren binnen de Overheid en het Onderwijs uiteenlopen. Vervolgens is ingegaan op de vraag in hoeverre werkgevers in de Overheid en het Onderwijs een goed active aging beleid hebben waarmee ze hun personeel met versoberde pensioenrechten intrinsiek weten te motiveren om langer door te werken. Tot slot is ingegaan op de mogelijke externe effecten die de versoberde pensioenrechten kunnen hebben op het pensioengedrag van partners.

Het blijkt dat het voeren van een goed active aging beleid cruciaal is om langer doorwerken te stimuleren. Financiële prikkels zijn slechts in beperkte mate effectief voor het verhogen van de arbeidsmarktparticipatie van oudere werkenden wanneer deze prikkels in onvoldoende mate gepaard gaan met een adequaat active aging beleid. De 
invoering van het $\mathrm{ABP}$ Keuzepensioen leidt tot een versobering in de pensioenrechten, waardoor werknemers I3 maanden langer moeten doorwerken om dit te compenseren. De verwachte pensioenleeftijd stijgt echter slechts met drie maanden. De effecten van de veranderingen in pensioenrechten blijken echter niet alleen beperkt te blijven tot degene die het pensioen zal ontvangen. Ook de partners van degenen met versoberde pensioenrechten stellen hun pensioen uit, eveneens met drie maanden.

In reactie op de versobering van hun pensioenrechten zijn werknemers meer gaan participeren in de levensloopregeling en nemen ze ook privé meer initiatief om te sparen voor hun pensioen. Hierdoor slagen werknemers er in om hun pensionering toch weer naar voren te schuiven. Deeltijdpensionering is daarentegen een weinig toegepast middel om de schok in het pensioenstelsel te compenseren, ondanks dat dit een belangrijk onderdeel is van het ABP Keuzepensioen.

Nog belangrijker is de conclusie dat het vergroten van de financiële prikkels om langer door te werken door het verminderen van de pensioenrechten negatieve consequenties heeft voor de duurzame inzetbaarheid van oudere werknemers. Werknemers die door de invoering van het ABP Keuzepensioen geconfronteerd werden met de versobering van hun pensioenrechten blijken minder tevreden te zijn met hun leven en hun baan en zijn ook vaker depressief. Omdat deze indicatoren sterk samenhangen met de inzet van werknemers op hun werk en het negatieve effect op het plezier in het werk na enkele jaren niet is verdwenen, is het zeer waarschijnlijk dat de versobering van de pensioenrechten op de lange termijn een negatief effect heeft op de productiviteit van oudere werknemers. Dit betekent dat een beleid dat zich louter richt op het geven van negatieve of positieve financiële prikkels om later met pensioen te gaan op gespannen voet staat met het doel om werknemers duurzaam en zo productief mogelijk te laten doorwerken. Het is zelfs waarschijnlijk dat de beperkte positieve prikkel op de arbeidsmarktparticipatie volledig teniet gedaan wordt door de verlaagde productiviteit. Gemiddeld genomen zullen werknemers die geboren zijn in I950 op het moment van de enquête immers na de invoering van het ABP Keuzepensioen nog ruim vier jaar moeten werken voordat zij hun verwachte pensioenleeftijd zullen bereiken.

Een belangrijke conclusie die uit deze resultaten kan worden getrokken is dat een effectief beleid gericht op duurzame inzetbaarheid en het voorkomen van knelpunten op de arbeidsmarktsegmenten die van belang zijn voor de sector Overheid en Onderwijs dus niet uitsluitend gericht moet zijn op het geven van financiële prikkels. Een daadkrachtig active aging beleid is noodzakelijk om de demotiverende werking van financiële prikkels te compenseren en de productiviteit van oudere werknemers op peil te houden.

Er kan echter worden geconstateerd dat in de beleving van de werknemers in de overheidssector en het onderwijs in 2009 nog niet in voldoende mate een adequaat active aging beleid wordt gevoerd. Het oordeel van de werknemers over het perso- 
neelsbeleid in hun organisatie blijkt zelfs vrij negatief te zijn. Opvallend is vooral dat veel werknemers negatief zijn over de moeite die hun werkgever neemt om het oudere personeel zo lang mogelijk aan het werk te houden. Daarnaast lijken werkgevers zich nog onvoldoende bezig te houden met het aanpassen van de taakbelasting van oudere werknemers wanneer dit in concrete situaties nodig is. Ook geven zij volgens de oudere werknemers in onze steekproef te weinig feedback over iemands ontwikkeling en doorgroeimogelijkheden.

Bovendien blijkt dat werknemers die minder pensioenrechten hebben vanwege de afschaffing van de FPU net zo negatief oordelen over het personeels- en ouderenbeleid van hun werkgever als degenen die zijn geboren in 1949 en nog steeds met FPU kunnen. Dit suggereert dat werkgevers nog geen of in ieder geval onvoldoende extra beleid hebben ontwikkeld voor de werknemers die langer door zullen moeten werken.

\section{Verschillen tussen sectoren}

In het rapport bleek dat er substantiële verschillen zijn in de pensioenverwachtingen en in het gevoerde personeelsbeleid. Tabel 6.I vat de belangrijkste conclusies van het rapport voor de verschillende sectoren samen. Werknemers in het Wetenschappelijk Onderwijs verwachten langer door te werken dan in andere sectoren. Daarentegen, verwachten degenen die werkzaam zijn in de sectoren Defensie Burger, Beroeps en Volwasseneneducatie en Water, Energie en Nutsbedrijven eerder uit te treden. De hogere leeftijd waarop de respondenten met pensioen denken te gaan in het Wetenschappelijk Onderwijs wordt echter niet veroorzaakt door de versoberde pensioenrechten als gevolg van de invoering van het ABP Keuzepensioen. Waarschijnlijker is dat werknemers in deze sector langer denken door te werken doordat zij een lagere pensioenuitkering verwachten op 62 jarige leeftijd en een hogere intrinsieke motivatie hebben voor hun werk. Meer onderzoek is nodig om de precieze oorzaak te achterhalen.

Een vergelijking van het 1949 cohort met diegenen die geboren zijn in 1950 laat verder zien dat vooral de werknemers in de sectoren Rijk, Gemeenten, Primair en Voortgezet Onderwijs en Water, Energie en Nutsbedrijven denken als gevolg van de versobering van hun pensioenrechten langer door te gaan werken. De invoering van het ABP Keuzepensioen heeft ervoor gezorgd dat de uitredeleeftijd van degenen die geboren zijn in 1950 in deze sectoren meer in lijn zijn komen te liggen met die in de overige sectoren.

Hoewel niet in alle sectoren de versobering van de pensioenrechten evenveel invloed heeft, geldt dat de impact van de pensioenhervorming op de verwachte pensioenuitkering op 62 jarige leeftijd in alle sectoren wel zichtbaar is. Desondanks verwachten werknemers in de sectoren Gemeenten en Water, Energie en Nutsbedrijven een relatief hoog pensioen te ontvangen op 62 jarige leeftijd. 


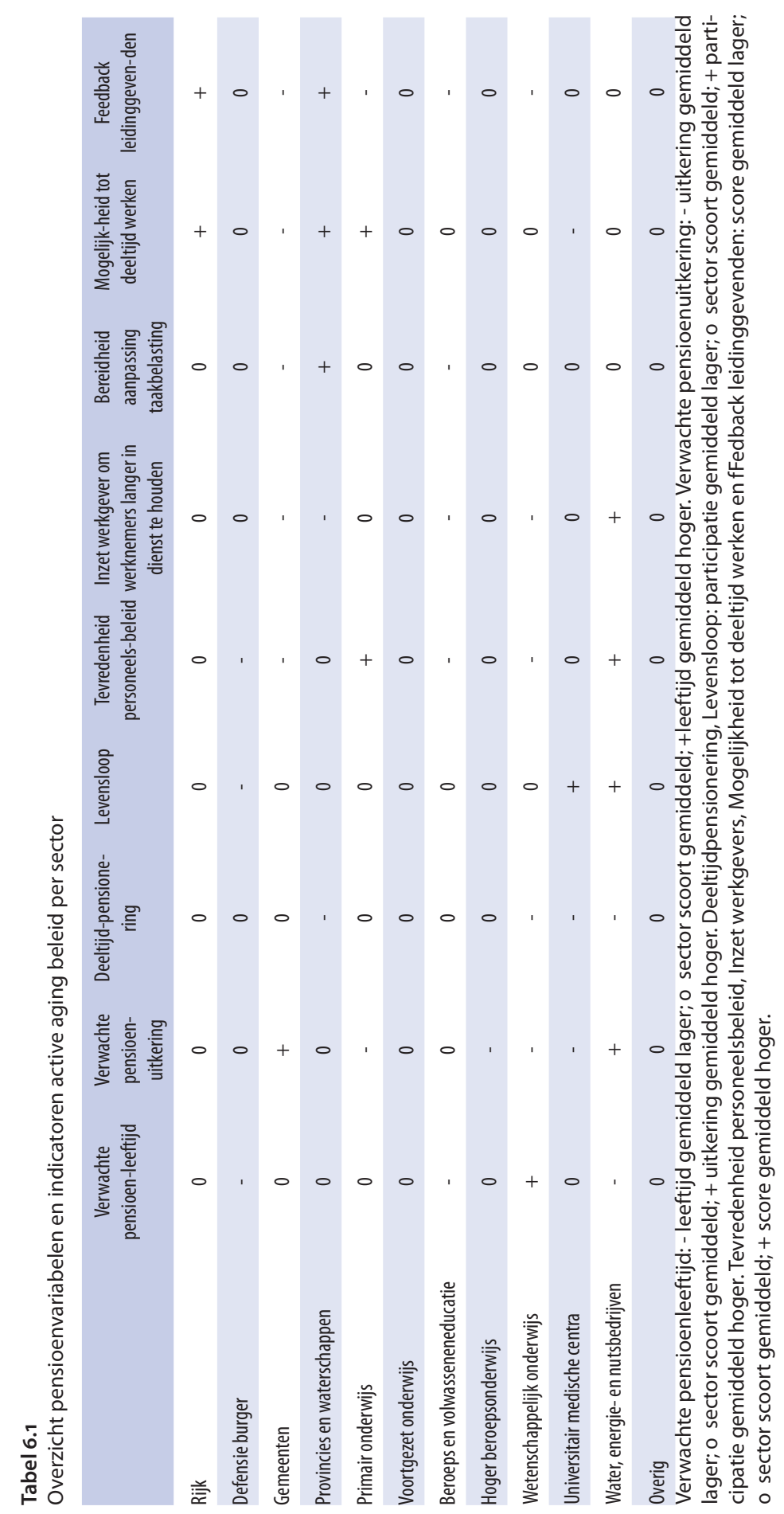


Wat betreft deeltijdpensionering en participatie in de levensloopregeling zijn er tussen de sectoren opmerkelijke verschillen zichtbaar. De verschillen in de mate waarin deeltijdpensionering wordt toegepast zijn vrij klein, maar voor de Provincies en Waterschappenen en UMC's vinden we een significant negatief effect van de invoering van de versobering van de pensioenrechten op de plannen om met deeltijdpensioen te gaan. Interessant is dat de werknemers met versoberde pensioenrechten in deze sectoren niet eerder denken uit te treden, terwijl hun verwachte pensioenuitkering wel significant lager is dan voor degenen die in 1949 geboren zijn. Het lijkt het er dus op dat de werknemers bij de Provincies en Waterschappenen en UMC's er voor kiezen om ondanks de afschaffing van de FPU hun pensioneringsplannen te handhaven en van deeltijdpensionering afzien om het ontstane pensioengat te beperken.

De participatie in de levensloopregeling is onder degenen die geboren zijn in 1950 aanzienlijk toegenomen in de Water, Energie- en Nutsbedrijven en de UMC's, waardoor in deze sectoren de participatie in de levensloop ook significant hoger ligt dan in andere sectoren. Daarentegen blijft de participatie in de levensloop betrekkelijk laag onder de werkenden bij Defensie $(4,4 \%)$.

De werkgevers in alle sectoren hebben niet voldoende ingespeeld op de veranderingen in het pensioenstelsel. Desondanks is de algehele tevredenheid met het personeelsbeleid van werknemers iets hoger in het Primair Onderwijs en de Water, Energie en Nutsbedrijven. Daarnaast geven werknemers aan dat in de Water, Energie en Nutsbedrijven ook sprake is van een relatief hoge inzet van de werkgever om hen langer aan het werk te houden. Verder oordelen werknemers wat positiever in de Provincies en Waterschappen en het Rijk.

Daarentegen, werknemers van de Gemeenten, Beroeps- en Volwasseneneducatie en in het Wetenschappelijk Onderwijs zijn het minst tevreden over het personeelsbeleid. Bovendien zijn werknemers in het Wetenschappelijk onderwijs die geboren zijn in I950 beduidend minder positief over de inzet van hun werkgever om werknemers langer in dienst te houden en de feedback die zij krijgen van hun directe leidinggevenden ten opzichte van degenen die geboren zijn in 1949. Dit duidt erop dat het toepassen van maatwerk in het personeelsbeleid in deze sector tot op heden achterblijft.

\section{Aanbevelingen}

Op basis van de resultaten van dit onderzoek kunnen enkele aanbevelingen worden gedaan, waarbij onderscheid kan worden gemaakt tussen beleidsaanbevelingen en aanbevelingen voor nader onderzoek. Voor de beleidsmakers zijn de volgende aanbevelingen relevant:

Sociale partners en werkgevers moeten meer aandacht besteden aan de productiviteitsagenda die gericht is op het langer productief doorwerken. Immers, de intrin- 
sieke motivatie van oudere werknemers voor hun werk wordt negatief beïnvloed door de recente veranderingen in het pensioenstelsel. Werkgevers moeten specifiek meer flexibel worden in het aanpassen van de taakbelasting van oudere werknemers en moeten meer oog hebben voor de ontwikkeling en doorgroeimogelijkheden van hun werknemers.

Op basis van dit onderzoek kan worden geconstateerd dat de sociale partners terughoudend dienen te zijn met het hanteren van verdere financiële prikkels tot het verhogen van de arbeidsmarktparticipatie, wanneer deze niet in combinatie met een goed active aging beleid worden doorgevoerd. De kans is groot dat zonder een goed active aging beleid het verhogen van de AOW leeftijd tot dezelfde negatieve effecten op de inzet en productiviteit van werknemers leiden als we zien bij de invoering van het ABP Keuzepensioen.

Er is meer maatwerk (zowel sectoraal als op werkgeversniveau) nodig in het active aging beleid. Werknemers met versoberde pensioenrechten zijn negatief over de inzet van hun werkgever om hun langer in dienst te houden.

Tevens is verder onderzoek nodig om tot een beter begrip te komen over hoe active aging beleid bijdraagt aan het langer productief doorwerken:

Het huidige onderzoek is uitsluitend gebaseerd op de percepties van werknemers. Voor vervolgonderzoek is het relevant dat ook werkgevers worden benaderd zodat een gedetailleerd beeld kan worden verkregen van de HRM-instrumenten die in de praktijk worden ingezet en in hoeverre in de verschillende sectoren het gevoerde active aging beleid kan worden verbeterd.

Jongere cohorten zullen zich in mindere mate getroffen voelen door de invoering van het ABP Keuzepensioen. Allereerst omdat de verhoogde pensioenpremie compenserend werkt. Ten tweede, omdat hun pensionering verder van hen afstaat. Het is daarom van belang om het onderzoek uit te breiden met jongere cohorten. Tevens is het relevant om ook data voor vrouwen te verzamelen die behoren tot deze jongere cohorten. Dit omdat het percentage vrouwelijke medewerkers per sector sterk verschilt. Het active aging beleid dat gevoerd wordt in de sectoren Provincies en Waterschappen en de Water, energie en nutsbedrijven biedt mogelijke aanknopingspunten voor het verbeteren van het beleid in de andere sectoren. Meer informatie is nodig om te achterhalen waarom werknemers in deze sectoren positiever oordelen over het gevoerde personeelsbeleid. 